\title{
REKONSTRUKSI BIOGRAFI DAN KARYA KIAI SHOLEH KUNINGAN BLITAR
}

\section{BIOGRAPHICAL RECONSTRUCTION AND WORKS OF KIAI SHOLEH KUNINGAN BLITAR}

\author{
Moch. Lukluil Maknun ${ }^{1}$ dan Arif Muzayin Shofwan ${ }^{2}$ \\ ${ }^{1}$ Badan Penelitian dan Pengembangan dan Pendidikan dan Pelatihan, \\ Kementerian Agama Republik Indonesia \\ ${ }^{2}$ Universitas Nahdlatul Ulama (UNU) Blitar, Indonesia \\ lukluilmaknun84@gmail.com
}

DOI: $10.31291 /$ jlka.v19.i2.942

Diterima: 15 September 2021; Direvisi: 15 Desember 2021;

Diterbitkan: 31 Desember 2021

\begin{abstract}
There were still many "Ulama Nusantara" who have scientific roles during their period with Syaikhona Kholil Bangkalan or K.H. Hasyim Asyari but were not exposed or studied much. One of those scholars who hasn't been widely known yet is Kiai Sholeh Kuningan Blitar, who produced The "Risalah Aqaid" book. This qualitative study, which used the character studies method and critical discourse analysis, tries to reintroduce Kiai Sholeh figures and his works. There are two important findings from this study. First, Kiai Sholeh Kuningan (1846-1948 AD) was one of the ulama in Blitar who became a referral person in studying Tauhid. He lived in the same era and related to Kiai Kholil, Kiai Sholeh Darat, K.H. Hasyim Asyari, and some other ulama. Based on the lineage, his father and grandfather were also referral persons in Islam matter, and he was the fifth descendant of Kiai Nur Iman Mlangi Yogyakarta. Second, Kiai Sholeh's works: "Risalah Aqaid Litauhid" can be considered as the development version of "Kitab Hasyiyah Ummul Barahin" because it was added more explanation from Mbah Sholeh views. This works, which was written in Arabic and Javanese Pegon, is still utilized as discussion material by his descendant and his santri/students until now.
\end{abstract}

Keyword: Tauhid, Akaid, Ummul Barahin. 


\begin{abstract}
ABSTRAK
Terdapat banyak tokoh Ulama Nusantara yang semasa dengan Syaikhona Kholil dan K.H. Hasyim Asyari dan berperan besar dalam keilmuan, tetapi belum dikenal secara luas. Salah satu dari tokoh ini adalah Kiai Sholeh Kuningan Blitar yang mewariskan karya 'Risalah Aqaid'. Secara kualitatif, kajian yang memanfaatkan metode studi tokoh dan analisis wacana kritis ini berupaya mengenalkan kembali figur sang tokoh berikut karyanya. Dua hal utama yang didapat dari kajian ini adalah: Pertama, Kiai Sholeh Kuningan (1846-1948 M) merupakan salah satu kiai di Blitar yang dijadikan rujukan bidang tauhid pada masanya. Ia semasa dan berhubungan dengan Kiai Kholil, Kiai Sholeh Darat, K.H. Hasyim Asyari, dan beberapa tokoh lainnya. Secara nasab, ayah dan kakeknya juga merupakan rujukan keilmuan pada masanya, selain ia juga keturunan kelima Kiai Nur Iman Mlangi Yogyakarta. Kedua, karya Kiai Sholeh 'Risalah Aqaid Litauhid' dari segi isinya dapat dianggap sebagai pengembangan dari kitab Hasyiyah Ummul Barahin yang ditambah pula dengan beberapa penjelasan versi Kiai Sholeh. Kitab yang ditulis dalam bahasa Arab dan Jawa Pegon ini masih terus hidup sebagai bahan kajian musyawarah maupun kajian kitab oleh ahli waris dan generasi murid-muridnya.
\end{abstract}

Kata Kunci: Tauhid, Akaid, Ummul Barahin.

\title{
PENDAHULUAN
}

Ketenaran Syaikhona Kholil Bangkalan (1835-1925) telah menarik banyak pengkaji dan penulis untuk mengabadikannya dalam kajian tokoh. Termasuk di dalamnya adalah kajian terhadap muridnya yang umumnya menjadi tokoh atau kiai besar khususnya di Jawa, seperti K.H. Hasyim Asyari, Kiai Abdul Wahab Hasbullah, Kiai Bisyri Syansuri, Kiai Abdul Manaf (Lirboyo), Kiai Maksum (Lasem), Kiai Munawir (Krapyak), Kiai Bisri Mustofa (Rembang), Kiai Nawawi (Sidogiri), Kiai Ahmad Shiddiq (Jember), Kiai As'ad Syamsul Arifin (Situbondo), dan masih banyak lagi ${ }^{1}$. Dapat dikatakan, tokoh atau cerita yang

${ }^{1}$ Zainal Anshari Marli, "Pemikiran Pendidikan Islam KH. Mohammad Kholil Bangkalan", Turats 7, no. 1 (2016); Mohammad Takdir, "Kontribusi Kiai Kholil Bangkalan Dalam Mengembangkan Tasawuf Nusantara," 'Anil Islam: Jurnal Kebudayaan Dan Ilmu Keislaman 9, no. 2 (2016): 268-99; Amirul Ulum, Muassis NU: Manaqib 26 Tokoh Pendiri Nahdlatul Ulama (Yogyakarta: Aswaja Pressindo, 2016); Umi Masfiah, "Pemikiran Pembaharuan K.H. Abdul Wahab Chasbullah Terhadap Lahirnya Nahdlatul 
dilekatkan atau berkaitan dengan Syaikhona Kholil akan selalu menarik untuk dibahas, terlebih jika ditemukan hal baru seperti karya tulis sang tokoh yang turut membantu rekonstruksi gambaran sejarah Islam Nusantara ${ }^{2}$.

Di antara tokoh yang diriwayatkan menjadi salah satu murid Syaikhona Kholil, tetapi belum banyak dikenal ataupun juga ditulis adalah sosok Kiai Sholeh Kuningan Blitar (w.1930). Nama Kiai Sholeh sempat muncul dalam barisan ulama masa perjuangan di sepanjang Sungai Brantas, tetapi hanya disebutkan sekilas oleh penulisnya ${ }^{3}$. Kisah hidup secara ringkas baru ditemukan di halaman website saja yang mengenalkannya sebagai pakar ilmu tauhid dan mengarang kitab "Risalah Aqaid", sebuah kitab nukilan kitab-kitab tauhid yang diberi penjelasan dengan huruf pegon, yang menarik banyak murid untuk mengaji kepadanya ${ }^{4}$.

Kajian ini berupaya mendalami dan mengenal kembali sosok Kiai Sholeh yang dinisbatkan sebagai salah satu murid Syaikhona Kholil melalui biografi dan karyanya. Dalam kajian tokoh, terdapat tiga indikator yang perlu diungkap, yaitu integritas, karya, dan kontibusinya bagi masyarakat ${ }^{5}$. Adapun

Ulama (NU)", International Journal Ihya' 'Ulum Al-Din 18, no. 2 (2017): 217, https://doi.org/10.21580/ihya.17.2.1737; Musfiroh Musfiroh, "Peran Hadratus Syaikh K.H. Hasyim Asyari dalam Pengembangan Hadis di Indonesia," Holistic Al-Hadis 5, no. 1 (2019): 1, https://doi.org/10.32678/ holistic.v5i1.3229; Budi Sujati Satria, "Gambaran Ahmad Dahlan dan Wahab Hasbullah Dalam Pendidikan Islam Terhadap Nasionalisme Indonesia," AlFikri 2, (2019): 28-36; Moh. Riwann Rifa'i, "Syaikhona Kholil Gurunya Para Kiai," nu.or.id, 2011.

${ }^{2}$ Muhamad Shoheh dan Muhammad Shofin Sugito, "Kitāb Seribu Masā'il Salinan dari Banten: Sebuah Konstruksi Sejarah Proses Islamisasi Nusantara," Jurnal Lektur Keagamaan 17, no. 1 (2019): 1-30, https://doi. org/10.31291/jlk.v17i1.599.

${ }^{3}$ Zainul Milal Bizawie, Masterpiece Islam Nusantara: Sanad dan Jejaring Ulama-Santri (1830-1945) (Tangerang Selatan: Pustaka Compass, 2016).

${ }^{4}$ Ahmad Karomi, "Kisah Kiai Sholeh Kuningan Blitar dan Anjing Milik Van Der Plas," halaqoh.net, 2019.

${ }^{5}$ Syahrin Harahap, Metodologi Studi Tokoh Pemikiran Islam (Jakarta: Istiqamah Mulya Press, 2006); Rahmadi Rahmadi, "Metode Studi Tokoh dan Aplikasinya dalam Penelitian Agama," Al-Banjari: Jurnal Ilmiah Ilmu-Ilmu 
karyanya berupa kitab diperdalam dengan analisis wacana kritis. Oleh karenanya, secara lebih fokus, kajian ini menjawab dua pertanyaan: 1) Bagaimana biografi Kiai Sholeh Kuningan Blitar, dan 2) Bagaimana deskripsi isi kitab Risalah Aqaidut Tauhid karya Kiai Sholeh Kuningan.

Peta penyebaran Islam di Jawa Timur terlebih daerah selain pesisir utara dan timur masih belumlah terang. Yang sudah ada barangkali lebih bersifat kedaerahan dan yang sudah masyhur karena tokohnya yang dikenal dalam lingkup nasional seperti pendiri-pendiri Nahdlatul Ulama dan guru-gurunya yang berjejaring keluar'. Adapun jejaring di ranah bawah, para 'kiai desa' yang melakukan transfer keilmuan Islam kepada masyarakat belum banyak diketahui ${ }^{7}$. Kajian ini diasumsikan dapat menyumbang pengetahuan pentingnya peran tokoh kiai lokal terutama sebagai jembatan pengetahuan dari ulama atau guruguru di tingkat/sanad atas kepada masyarakat di bawah. Selain itu, melalui kajian seperti ini dapat menguatkan gambaran keberadaan tradisi keislaman lokal atau keislaman priyayi yang berbeda dengan tradisi keislaman Timur Tengah.

\section{Kerangka Konsep}

Sebagai pengantar dipaparkan konsep studi tokoh berikut definisi kiai yang merupakan objek pertama dari kajian, serta konsep ilmu akaid/ilmu kalam/tauhid yang dinisbatkan pada karya tokoh yang dikaji. Studi tokoh adalah kajian ilmiah terhadap orang terkemuka dalam bidang tertentu, yang dalam hal ini dikhususkan pada pendefinisian sebagian atau keseluruhan pemikiran/gagasan pemikir/tokoh muslim. Sebagai penentu karakte-

Keislaman 18, no. 2 (2019): 274, https://doi.org/10.18592/al-banjari.v18i2. 2215.

${ }^{6}$ Azyumardi Azra, Jaringan Ulama Timur Tengah Dan Kepulauan Nusantara Abad XVII \& XVIII: Akar Pembaruan Islam Indonesia (Jakarta: Kencana, 2004); Setiyawan, "Sejarah Islam Nusantara Menurut Azyumardi Azra", Journal of Chemical Information and Modeling 53, no. 9 (2013): 1689-99; Amirul Ulum, Muassis NU: Manaqib 26 Tokoh Pendiri Nahdlatul Ulama.

${ }^{7}$ Bizawie, Masterpiece Islam Nusantara: Sanad Dan Jejaring UlamaSantri (1830-1945). (Tangerang Selatan: Pustaka Compass, 2016). 
ristik tokoh yang dikaji, perlu diajukan setidaknnya tiga indikator. Pertama, integritas tokoh yang dilihat dari moralitas, keilmuan, kepemimpinan, dan keberhasilan tokoh dalam hal yang digeluti. Kedua, karya monumental tokoh baik fisik atau non fisik yang bermanfaat bagi masyarakat. Ketiga, kontribusi dan pengaruh tokoh dalam bentuk pemikiran, kepemimpinan, dan keteladanan $^{8}$. Di antara tujuan studi tokoh yang ideal adalah memperoleh gambaran utuh sosok tokoh, metodologi yang digunakan tokoh dalam karyanya/kiprah keilmuannya, orisinalitas karyanya, serta relevansi dan kontekstualisasi pemikiran tokoh dengan konteks kekinian? ${ }^{9}$.

Kiai dapat dideskripsikan sebagai tokoh agama Islam yang diberi kepercayaan masyarakat mengajarkan ilmu-ilmu agama Islam, menjadi panutan, serta identik memiliki pesantren atau tempat mengajar para murid/santri. Kiai identik dengan ulama yaitu tokoh bagian dari umat yang memegang peran penting dalam membentuk karakter masyarakat sekitarnya ${ }^{10}$.

Kepakaran dan karya dari Kiai Sholeh Kuningan Blitar adalah di bidang tauhid/akaid/atau bisa juga dikenal dengan ilmu kalam. Ilmu kalam adalah ilmu yang membahas keesaan Allah, kerasulan, wahyu, kitab suci Alquran, persoalan mukmin dan muslim, pembahasan hubungan manusia dengan pencipta, serta persoalan surga dan neraka. Ilmu kalam disebut pula ilmu tauhid karena membahas wujud Allah, sifat-sifat-Nya, serta para Rasul dan sifatnya. Ilmu kalam mengidentifikasi akidah pokok dan

${ }^{8}$ Syahrin Harahap, Metodologi Studi Tokoh Dan Penulisan Biografi (Jakarta: Prenadamedia Group, 2014); Rahmadi, "Metode Studi Tokoh Dan Aplikasinya Dalam Penelitian Agama"; Syahrin Harahap, Metodologi Studi Tokoh Pemikiran Islam. (Jakarta: Istiqamah Mulya Press, 2006).

${ }^{9}$ Rahmadi, "Metode Studi Tokoh Dan Aplikasinya Dalam Penelitian Agama.” Jurnal Ilmiah Ilmu-Ilmu Keislaman 18 (2): 274.

${ }^{10}$ Ahmad Muhakamurrohman, "Pesantren: Santri, Kiai, Dan Tradisi," IBDA ` Jurnal Kajian Islam Dan Budaya 12, no. 2 (1970): 109-18, https:// doi.org/10.24090/ibda.v12i2.440; Zamakhsyari Dhofier, Tradisi Pesantren: Studi Tentang Pandangan Hidup Kiai (Jakarta: LP3ES, 1982); Mustolehudin Mustolehudin dan Siti Muawanah, "Pemikiran Pendidikan K. H. Ali Maksum Krapyak Yogyakarta," EDUKASI: Jurnal Penelitian Pendidikan Agama Dan Keagamaan 16, no. 1 (2018): 18-34, https://doi.org/10.32729/edukasi. v16i1. 441. 
berupaya membuktikan keabsahannya dan menjawab keraguan terhadapnya ${ }^{11}$.

\section{Metode}

Kajian ini bertujuan untuk mengungkap dan membentuk kembali biografi tokoh Kiai Sholeh Kuningan. Tokoh ini dipilih karena belum banyak dikenal umum sebagai salah satu tokoh penting di Blitar khususnya, yang merupakan salah satu murid Syaikhona Kholil. Selain biografi tokoh, kajian ini akan mendeskripsikan secara kritis kitab karya Kiai Sholeh.

Sebagai artikel kualitatif, kajian ini lebih banyak menggunakan data yang bersumber dari observasi, studi dokumen, dan wawancara. Observasi utamanya dilakukan untuk mengamati peninggalan dari Kiai Sholeh serta kondisi tempat tinggalnya pada masa sekarang. Studi dokumen dilakukan untuk mengkaji teks utama kitab Kiai Sholeh (copy kitab) serta dokumen pendukung yang terkait. Wawancara dilakukan terhadap orang-orang dekat (keturunan dan keluarga) Kiai Sholeh serta tokoh-tokoh yang berhubungan dengannya secara snowball. Selanjutnya data yang terhimpun dilakukan keroscek silang kepada para narasumber serta kajian dan dokumen yang sudah ada terkait tokoh yang ditulis.

Setelah data terkumpul, dilakukan klasifikasi untuk kemudian dilakukan analisis tokoh dengan menjawab tiga indikator utama (integritas, karya, dan kontribusi tokoh) ${ }^{12}$. Adapun karya/ kitabnya dianalisis lebih lanjut menggunakan analisis wacana kritis (AWK). AWK secara ideal dimaksudkan untuk mengkaji lebih dalam sebuah isi wacana yang dalam hal ini berwujud teks kitab karya ulama yang tidak lepas dari konteks sosial yang melingkupinya. Secara sederhana AWK dalam kajian ini sedikit banyak menyandingkan konteks masa penulisan karya Kiai

${ }^{11}$ Umi Masfiah, "Pemikiran Kalam Kiai Muhammad Sami'un Purwokerto dalam Naskah Aqaid 50", Jurnal SMART (Studi Masyarakat, Religi, Dan Tradisi) 3, no. 2 (2017): 207, https://doi.org/https://doi.org/ 10.18784/smart.v3i2.

${ }^{12}$ Syahrin Harahap, Metodologi Studi Tokoh Pemikiran Islam; Rahmadi, "Metode Studi Tokoh Dan Aplikasinya Dalam Penelitian Agama." (Jakarta: Istiqamah Mulya Press, 2006). 
Sholeh, yang jika disandarkan pada konsep Fairclough masuk pada dimensi ketiga yaitu praktik sosial budaya yang berkembang saat $i u^{13}$.

\section{HASIL DAN PEMBAHASAN}

Ulama Blitar di lingkungan pesantren banyak dikenal dengan spesialisasi bidang akaid dan tasawuf. Satu di antaranya adalah Kiai Sholeh atau yang lebih akrab dengan nama Mbah Sholeh merupakan salah satu ulama Blitar yang dijadikan rujukan dan diceritakan semasa dengan Kiai Khalil Bangkalan dan Kiai Sholeh Darat ${ }^{14}$. Sebagai hasil kajian dipaparkan data dan analisis penulis berupa rekonstruksi biografi Mbah Sholeh, meliputi nasab keturunan, nasab keilmuan, integritas tokoh, kontribusinya yang utama berupa masjid dan kitab akaid, sampai kepada wafatnya. Data dan analisis berikutnya berupa kajian kritis terhadap karya Mbah Sholeh yaitu kitab Aqaidut Tauhid.

\section{1) Nasab Keturunan}

Mengenal Kiai Sholeh Kuningan Blitar ini tidak lengkap jika tidak mencari tahu sosok kakek dan ayahnya yang juga merupakan ulama berpengaruh di Blitar. Sang kakek bernama Kiai Abu Hasan, sedangkan sang ayah yang bernama Kiai Abu Manshur adalah menantu laki-laki Kiai Abu Hasan, yang menikahi Nyai Martinah/Maryam binti Abu Hasan.

H. M. Kirom Sidik, keturunan keempat dari Kiai Abu Hasan, menceritakan bahwa kakek buyutnya merupakan pejuang dari Mataram yang ditugaskan untuk menyebarkan agama di seberang wetan dan dipilihlah daerah Blitar - tepatnya di daerah

${ }^{13}$ Yoce Aliah Darma, Analisis Wacana Kritis (Bandung: Yrama Widya, 2009); Nurochim Nurochim et al., "Multikulturalisme: Analisis Wacana Kritis Terhadap Teks Dalam Buku Ajar Pendidikan Agama Islam," Jurnal Lektur Keagamaan 18, no. 1 (2020): 197-222, https://doi.org/10.31291/jlk.v18i1. 775 .

${ }^{14}$ Ahmad Karomi, "Kisah Kiai Sholeh Kuningan Blitar Dan Anjing Milik Van Der Plas.” Halaqoh.Net. 2019. https://www.halaqoh.net/2019/11/ kisah-kiai-sholeh-kuningan-blitar-dan.html?m=1 (2019); wawancara dengan Arif Muzayin Shofwan, 8 Juli 2020; wawancara dengan Miftachuddin, 9-11 Juli 2020) 
Kuningan- karena sudah ada Raden Aryo Blitar yang juga keturunan Mataram. Di Kuningan, Kiai Abu Hasan membuat masjid dan pesantren yang diberi nama Nurul Huda. Di antara peninggalan yang ada di masjid adalah mimbar yang mirip dengan bentuk mimbar Mataram. Salah satu santri Kiai Abu Hasan adalah Kiai Said/Sahid yang diklaim sebagai salah satu guru Kiai Hasyim Asyari. Kiai Abu Hasan wafat pada 1899 dengan usia 109 tahun $^{15}$.

Syaikh Abu Hasan (1790-1899 M) lahir di Kuningan Kanigoro Blitar. Pada usia remaja belajar di Mambaul Ulum, madrasah diniyah keraton Yogyakarta, hingga ia diangkat sebagai penghulu keraton. Pada usia 29 tahun Syaikh Abu Hasan mendapatkan anugrah tombak Dwi Sula (tanda penghulu taat dan bermartabat dan bersiap jihad sabilillah). Pada umur 29 ini, tepatnya tahun 1819 hijrah ke Blitar pada masa bupati Aryo Blitar, kemudian bermukim di daerah Kawuningan (Kuningan saat ini) yang awalnya merupakan taman dan kolam ikan milik bupati. Di Kuningan, Syaikh Hasan mendirikan pesantren Nurul Huda. Syaikh Abu Hasan dikaruniai 4 putera dan 3 puteri ${ }^{16}$.

Syaikh Abu Hasan konon masih bersaudara dengan Syaikh Abu Syamsuddin (Syaikh Su'aedi) Batu Ampar Sampang Madura, bahkan diklaim lebih tua (saudara tua). Sumber cerita ini di antaranya: Kiai Ali Amir dan Kiai Ali Yasin (keduanya pengasuh Pondok Pesantren Darussalam Gaprang Kanigoro Blitar, yang masih keturunan Syaikh Abu Hasan); Kiai Muhtar Fauzi, Kiai Nasruddin, dan Kiai Imam Mahdi (ketiganya pengasuh Pondok Pesantren Miftahul Huda Sekardangan Kanigoro Blitar; dan Kiai Zainuddin Sekardangan (menantu Kiai Ridwan Pondok Pesantren Karangsono Kanigoro Blitar). Penelusuran silsilah nasab Syaikh Abu Hasan dan Syaikh Su'aedi Batu Ampar dilanjutkan dengan bertanya kepada Kiai

15 Roby Ridwan, “Jejak Pasukan Diponego Penyebar Agama Islam Di Blitar," Youtube.com, 2018.

16 "Sejarah Singkat Wisata Religi Syaikh Abu Hasan Syaikh Abu Manshur Kuninangan Kec. Kanigoro Blitar,” 2019, n.d. http://syaikhabuhasan kuningan.blogspot.com 
Ali Amir Gaprang yang konon punya catatan silsilah. Sayangnya saat dijumpai, dokumen tersebut sudah tidak ada ${ }^{17}$.

Keterkaitan atau hubungan antara Syaikh Abu Hasan dengan Syaikh Su'aedi ini dipahami dua macam. Pertama, diyakini sebagai hubungan keturunan/darah ${ }^{18}$. Kedua, dipahami sebagai hubungan nasab keilmuan. Pendapat kedua ini ditegaskan oleh Haikal Asfari yang mengaku pernah melakukan penelusuran hal ini ke pihak keluarga keturunan Syaikh Su'aedi Batu Ampar Madura ${ }^{19}$.

Syaikh Abu Manshur (Ayah Kiai Sholeh) adalah keturunan Bendhoro Pangeran Hangabei Sandeyo/K.H. Nur Iman Mlangi Yogyakarta. Syaikh Abu Manshur masuk pada barisan Pangeran Diponegoro. Hingga peristiwa ditangkapnya Pangeran Diponegoro, Syaikh Abu Manshur beserta para pasukan dan 158 pangeran lainnya menyebar dan menyamar untuk melestarikan dakwah dan tetap menghimpun barisan dengan kode Sawo Kecik, sawo dari redaksi sawwu sufuufakum. Syaikh Abu Manshur pun memilih tinggal berguru ke Syaikh Abu Hasan di Blitar yang dulunya merupakan gurunya di Mambaul Oelum. Syaikh Abu Manshur akhirnya dinikahkan dengan Maryam, puteri bungsu Syaikh Abu Hasan hingga dikaruniai 9 anak ${ }^{20}$.

Secara lebih lengkap, silsilah Syaikh Abu Hasan dan putra putrinya dapat dilihat pada gambar 1 dan 2.;

Gambar 1 menunjukkan secara nasab, Syaikh Abu Manshur adalah keturunan kelima dari R.Mas Besari/Kiai Nur Iman Mlangi. Jika ditarik ke atas lagi, nasabnya menyambung kepada keturunan Maulana Ishaq sampai kepada Nabi Muhammad Saw.

17 Wawancara dengan Arif Muzayin Shofwan, 8 Juli 2020; wawancara dengan Miftachuddin, 9-11 Juli 2020.

18 Wawancara dengan Miftachuddin, 9 Juli 2020; Arif Muzayin Shofwan, 8 Juli 2020; Al-Djaeni, 22 Juli 2020.

${ }^{19}$ Wawancara dengan Haikal Asfari, 15 Juli 2020.

20 "Sejarah Singkat Wisata Religi Syaikh Abu Hasan Syaikh Abu Manshur Kuninangan Kec. Kanigoro Blitar." 


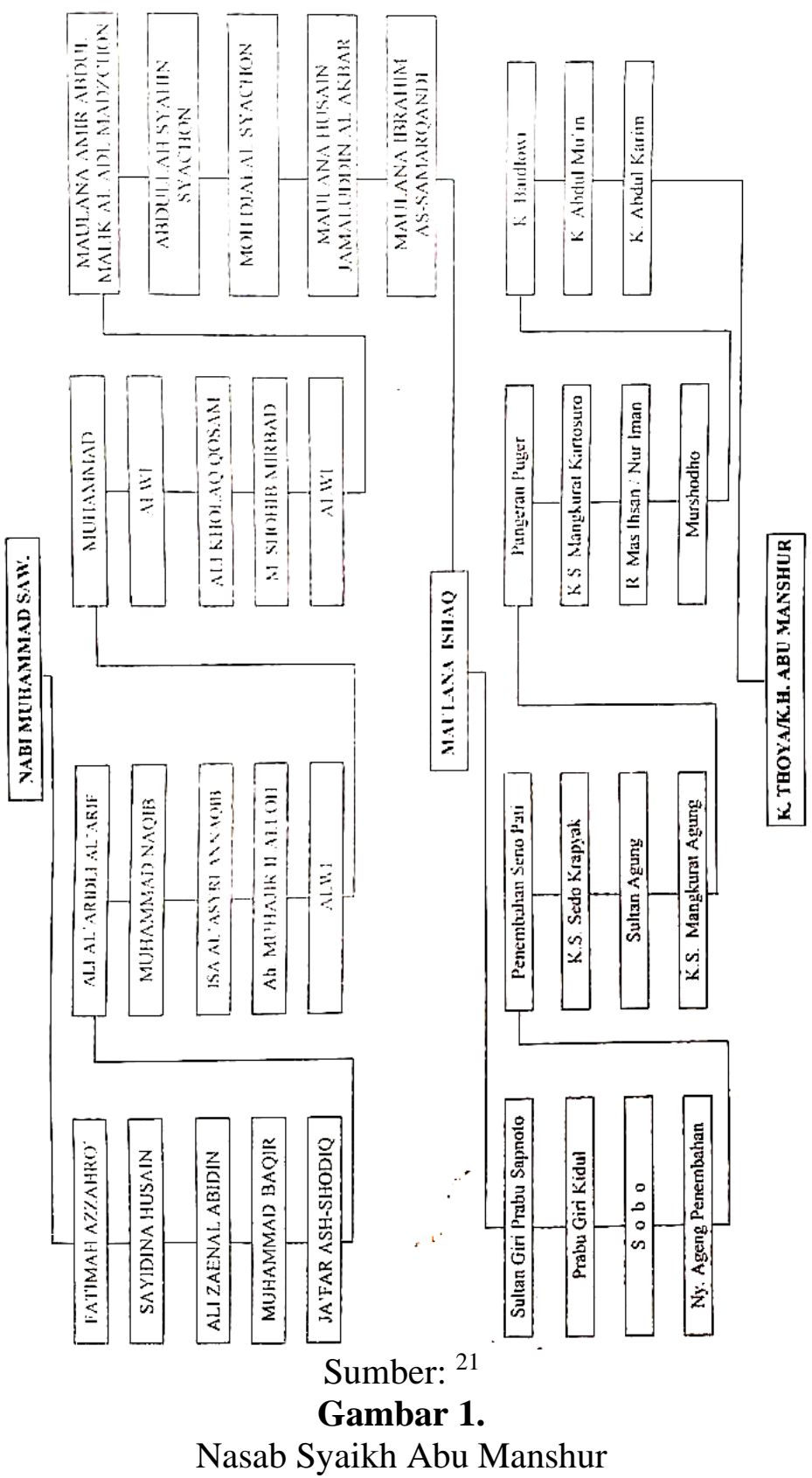

${ }^{21}$ Moh. Jamal Abdul Nasher et al., Buku Silsilah Keluarga Besar KH. Abu Manshur Kuningan (Blitar, 2002). 


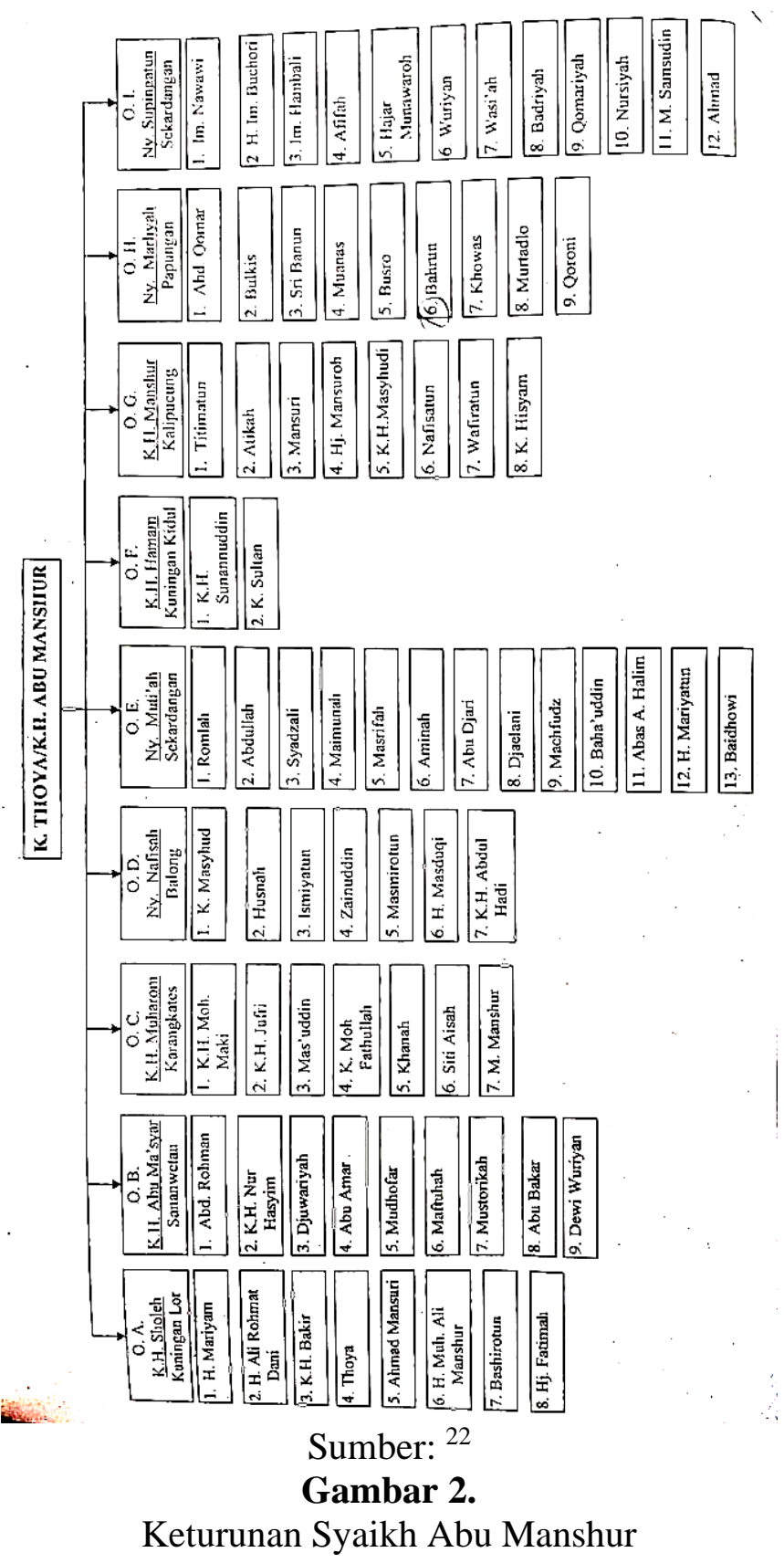

${ }^{22}$ Nasher et al. 
Gamber 2 mendeskripsikan sembilan putra putri Kiai Abu Manshur hingga pada generasi cucu. Hasil pernikahan Kiai Abu Manshur dengan Nyai Martinah melahirkan sembilan keturunan; 1) KH. Sholeh, 2) KH. Abu Mahsyar/Maksum, 3) KH. Muharrom/Muhsin Karangkates Kediri, utara pondok Ploso Kediri, 4) Ny. Nafisah, Mbalong Sambi Kediri, 5) Ny. Muthiah, Sekardangan/istri KH. Imam Faqih 6) KH. Hamam, 7) KH. Mansur, Kalipucung 8) Ny. Marliah, Papungan dan 9) $\mathrm{Ny}$. Supingatun, Sekardangan ${ }^{23}$.

Kiai Sholeh merupakan putra pertama dari Kiai Abu Manshur dengan Nyai Martinah. Waktu kelahiran dan wafat Mbah Kiai Sholeh belum dapat dipastikan hingga artikel ini ditulis. Informasi yang diingat dan didengar Miftachuddin terkait hal ini pertama, Mbah Kiai Sholeh masih berpartisipasi pada peristiwa 10 November dengan memberikan asma (doa) dan pembekalan kepada para pejuang meskipun tidak ikut turun dalam peperangan. Kedua, usia Mbah Kiai Sholeh lebih dari seratus tahun. Keterangan tambahan yang disampaikan Haikal Asfari selaku Buyut Mantu dinyatakan bahwa berdasar hasil perhitungan yang telah dihimpun, Mbah Kiai Sholeh diperkirakan lahir pada $1846 \mathrm{M}$ dan wafat pada $1948 \mathrm{M}^{24}$. Kiai Sholeh dimakamkan di komplek pemakaman Syaikh Abu Hasan Kuningan, bersama kakek, ayah, dan saudara-saudaranya.

Mbah Kiai Sholeh pada masa hidupnya beristrikan empat orang; 1) Nyai $\mathrm{Hj}$. Tasmirah, 2) Nyai Hj. Sapurah, 3) Nyai Mutiah, dan 4) Nyai Kamirah. Secara lebih lengkap hal ini dapat dilihat pada gambar 3 .

Gambar 3 menunjukkan bahwa dari empat isteri, Mbah Kiai Sholeh dikaruniai delapan keturunan. Dari isteri pertama dilahirkan $\mathrm{Hj}$. Mariyam. Dari isteri kedua dilahirkan KH. Ali Rahmadani, KH. Bakir Soleh, dan M. Thoya. Dari isteri ketiga dilahirkan Ahmad Mansuri, H. M. Ali Mansur, dan Hj. Fatimah. Kemudian dari isteri keempat dilahirkan $\mathrm{Hj}$. Basirotun ${ }^{25}$.

\footnotetext{
${ }^{23}$ Wawancara dengan Miftachuddin, 9 Juli 2020

${ }^{24}$ Wawancara dengan Miftachuddin dan Haikal Asfari, 11 Juli 2020

${ }^{25}$ Wawancara dengan Miftachuddin, 9 Juli 2020
} 
REKONSTRUKSI BIOGRAFI DAN KARYA KIAI SHOLEH KUNINGAN BLITAR - Moch. Lukluil Maknun dan Arif Muzayin Shofwan

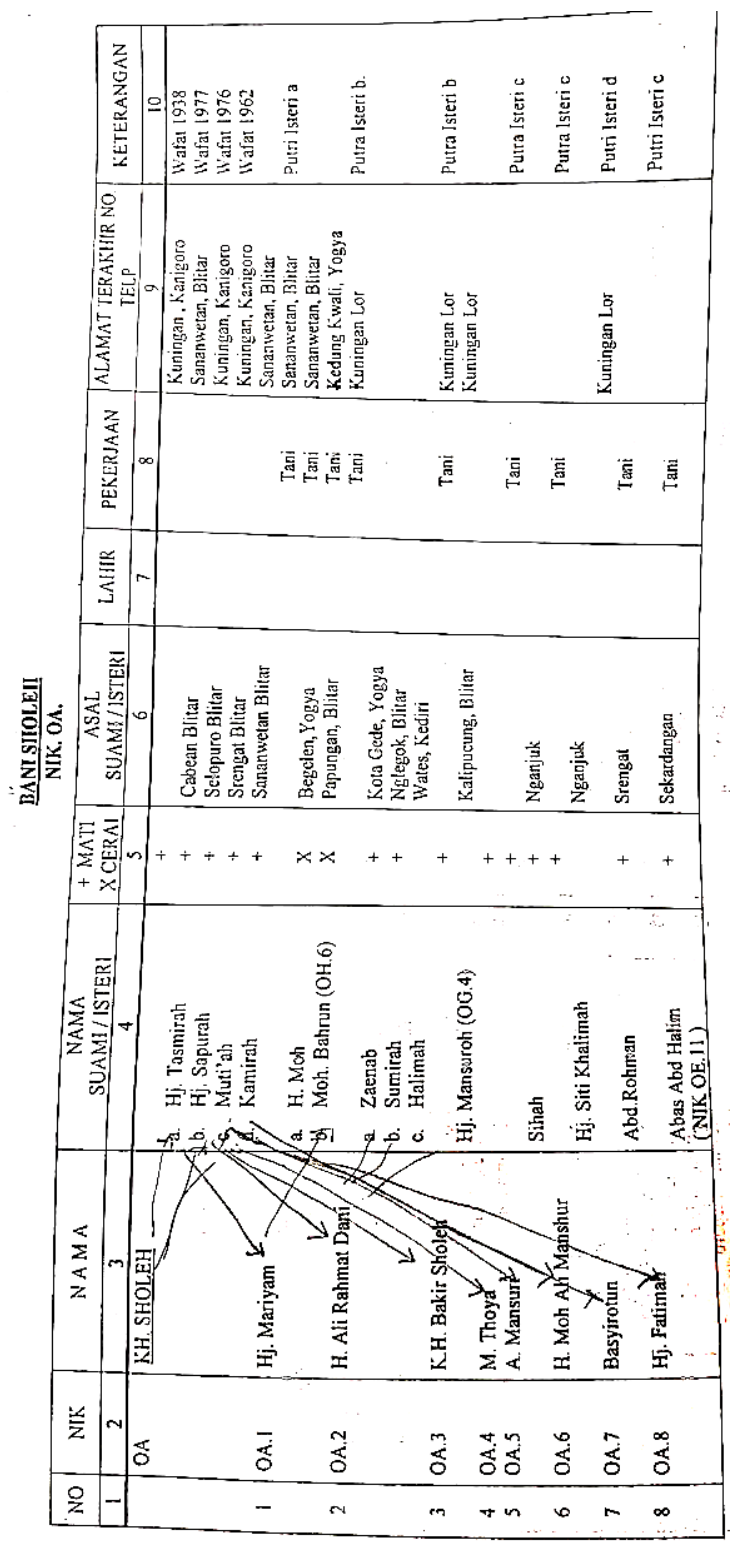

Sumber: ${ }^{26}$

Gambar 3.

Nasab Bani Sholeh

${ }^{26}$ Nasher et al. 


\section{2) Nasab Keilmuan}

Kiai Sholeh terkenal karena diklaim pernah nyantri kepada Kiai Kholil Bangkalan dan mengarang Kitab Aqaid. Setelah ditelusur, nasab keilmuan Kiai Sholeh hingga membuahkan karya tidak hanya wasilah nyantri kepada Kiai Kholil. Di antara guru Kiai Sholeh adalah: Mbah Abu Manshur/ayah, Mbah Kholil Bangkalan, Mbah Matlab Jepun Blitar, Kiai Soleh Darat, Pengasuh Ponpes Mojosari Nganjuk, serta para guru di Makkah $^{27}$.

Setelah memperoleh bekal dari sang ayah, Kiai Sholeh melanjutkan menimba ilmu ke Makkah. Bersama salah satu isteri, $\mathrm{Hj}$. Sapurah, Kiai Sholeh menimba ilmu kepada para guru di Makkah beberapa lama. Informasi yang terhimpun, Kiai Sholeh pulang bersama $\mathrm{Hj}$. Sapurah dan putranya Ali Rahmadani. Sang putra ini masih diperdebatkan entah lahir di Blitar kemudian diajak serta ke Makkah, atau lahir di Makkah saat Kiai Sholeh belajar ${ }^{28}$.

Kiai Sholeh juga menimba ilmu di Mojosari Nganjuk. Sayangnya, sanad gurunya di Mojosari belum terlacak, demikian halnya guru-gurunya di Makkah. Bukti Kiai Sholeh berhubungan erat dengan pondok Mojosari di antaranya karena kitab karyanya disalin oleh santri Mojosari Nganjuk. Salinan tersebutlah yang kemudian dapat dijumpai dan tersebar hingga saat ini.

Kiai Sholeh juga berhubungan murid-guru terhadap beberapa kiai pada masanya. Miftachuddin pernah mendengar bahwa Kiai Sholeh dulu juga mengaji kepada Kiai Matlab Jepun Selopuro Blitar, salah satu tokoh kiai Akaid dan Tasawuf pada masanya. Diceritakan, bahwa lama ngajinya hanya sekitar 3 bulanan. Kiai Sholeh juga pernah bertemu muka dan berhubungan murid-guru kepada Kiai Sholeh Darat, entah berapa lama. Selanjutnya Kiai Sholeh demikian juga sang adik Kiai Mansyur/Kiai Mansyur Bambu Runcing berguru pula kepada Kiai Kholil Bangkalan ${ }^{29}$.

\footnotetext{
27 Ibid

${ }^{28}$ Ibid

${ }^{29}$ Wawancara dengan Miftachuddin, 9 Juli 2020
} 
Kisah nyantri Kiai Sholeh dan Kiai Mansyur kepada Kiai Kholil sebenarnya dapat digali dari banyak informan karena menurut Miftachuddin dalam forum pengajian kitab Mbah Sholeh dulu sering diriwayatkan kisah itu. Kiai Kholil dikenal luas sebagai kiai yang khariqul adat (berbeda dengan kiai pada umumnya, memiliki keistimewaan dan banyak karomah). Demikian pula saat memperlakukan Kiai Mansyur dan Kiai Sholeh. Dari beberapa cerita, Kiai Mansyur lebih dulu nyantri kepada Kiai Kholil, karena Kiai Sholeh berlaku sebagai anak tertua memilih untuk membantu orang tua mencari nafkah dan ikut menghidupi adik-adiknya ${ }^{30}$.

Adapun kisah Kiai Sholeh saat hendak nyantri kepada Mbah Kiai Kholil Bangkalan di antaranya diceritakan oleh AlDjaini berikut.

"Ada cerita dari Kiai Isroil Blitar bahwa pernah ada kejadian saat Mbah Sholeh nyantri ke Mbah Kholil Bangkalan. Saat itu Mbah Kholil mengumpulkan para santri agar mempersiapkan diri kedatangan macan, dan meminta para santri membawa pentungan. Setelah menunggu beberapa saat, tiba ada rombongan kecil, ada orang naik tandu/pikulan. Seketika Mbah Kholil mengatakan: "itu macannya, yang dipikul." Para pemukul tamu seketika meletakkan tandu dan lari karena takut dengan para santri yang mengejar sambil membawa pentungan. Demikian pula Mbah Sholeh yang ada dalam tandu, akhirnya lari pulang, tidak jadi menemui Mbah Kholil. Usut punya usut, ternyata yang dimaksud macan adalah singa tauhid. Dengan demikian, dapat dikatakan antara Mbah Kholil dan Mbah Sholeh itu belum sampai saling belajar mengajar secara muwajahah (tatap muka), melainkan cukup dengan kontak batin. Dari cerita ini dapat diasumsikan pula bahwa kedua tokoh ini memiliki makam yang tidak dapat dianggap remeh, bisa dianggap keduanya memiliki makam wali." 31

Dua kisah ringkas belajarnya Kiai Mansyur dan Kiai Sholeh kepada Kiai Kholil Bangkalan ini memperkaya ketokohDer Plas."

${ }^{30}$ Karomi, "Kisah Kiai Sholeh Kuningan Blitar Dan Anjing Milik Van

${ }^{31}$ Wawancara dengan Al-Djaini, 22 Juli 2020 
an Kiai Kholil yang dikenal 'aneh'. Banyak kisah lain yang memiliki benang merah yang berdekatan bahwa santri yang belajar kepada Kiai Kholil banyak yang tidak diajari secara nyata pembelajaran kitab, bisa jadi hanya diberikan pembelajaran hikmah dan tindakan yang kadangkala susah ditangkap oleh nalar. Meskipun demikian hasil dari niat santri untuk belajar kepada Kiai Kholil dan karomah sang kiai sudah memberikan banyak atsar (bukti dan akibat) yang mengantarkan santri menjadi tokoh besar.

\section{3) Integritas}

Gambaran kepribadian dan cerminaan sikap dari Kiai Sholeh utamanya kesesuaian sikap dan perilaku dengan pemikiran serta gagasan keilmuannya dapat dipetik dari rangkaian kisah yang penulis dapatkan dari beberapa informan. Di antara sikap utama yang dimiliki oleh Kiai Sholeh adalah memegang erat prinsip agama. Ketegasan pada prinsip ini tidak jarang membuat lawan bicara atau orang yang melihatnya sebagai hal aneh, kolot, atau sejenisnya.

Di antara cerminan hal ini, dulu Kiai Sholeh hampir tidak pernah terlihat memakai celana panjang. Ia kemana mana memakai sarung. Barangkali hal ini merupakan perwakilan atau lambang ketidaksukaannya kepada pihak penjajah dan tidak ingin menggunakan perabot yang mirip penjajah. Bahkan saat berada di sawah atau di kebun, Kiai Sholeh tetap bersarung yang digunakan seperti cawat.

Sikap dan mungkin juga candaan Kiai Sholeh dalam beberapa cerita juga sangat kental dengan nuansa tauhid. Salah satu imbas dari hal ini membuat orang menganggap Kiai Sholeh sebagai sosok yang kereng (keras, pemarah). Sebagai contoh, saat ada orang datang ditanyai, "Kamu kesini dengan siapa?", kemudian dijawab "Saya datang sendiri", maka orang tersebut lalu ditempeleng, karena seharusnya dijawab, "bersama Allah"32. Dalam satu sisi, sikap ini benar secara akidah, tetapi disampaikan dengan cara 'bercanda' versi Kiai Sholeh.

${ }^{32}$ Karomi, 2019; Wawancara dengan Miftachuddin, 11 Juli 2020) 
Kuatnya pemahaman dalam hal tauhid juga membuat Kiai Sholeh dikenal sebagai Kiai yang ahli politik (di daerah setempat, Blitar/Jawa Timur, berpolitik dapat dimaknai sebagai orang yang pandai konfrontasi, berdebat, bersilat lidah, atau juga mengelabui). Miftachuddin memberikan beberapa kisah terkait hal ini.

"Mbah Sholeh termasuk orang kaya. Tiap kali pergi ia sering naik bendi/dokar. Sementara saat itu dokar kendaraan mewah yang hanya orang-orang tertentu yang bisa menaikinya. Saat keluar sering berpapasan dengan petugas/polisi yang dulu membawa pentungan. Saat polisi ingin mencegat dan menertibkan Mbah Sholeh, ternyata gagal, Mbah Sholeh malah lebih dulu memukul para polisi. Di lain hari, Mbah Sholeh tetap bisa lolos dari jerat petugas, karena ia tidak naik dokar, tetapi naik kuda, sehingga tidak terjerat aturan, meskipun kuda sendiri pada masa itu juga kendaraan mewah yang hanya umumnya dinaiki pejabat. Jadi saat berkasus dengan polisi, itu selalu menang. Di lain cerita, dulu Mbah Sholeh bilang, "kalau ada apa-apa 'nyokoto' aku”, dalam arti ia akan terjun menyelesaikan perkara, termasuk misalnya ada orang yang membunuh orang, maka Mbah Sholeh yang dimintai tolong akan bisa membantu dan menang. "33

Cerita tersebut merupakan cerminan Kiai Sholeh pandai dalam hal konfrontasi, beradu argumen, meskipun contoh redaksi secara lengkapnya tidak bisa diceritakan oleh informan. Berkasus dengan polisi dapat diibaratkan dengan melanggar aturan yang sudah dibuat pemerintah saat itu. Akan tetapi, pemerintah yang ada saat itu menurut Kiai Sholeh mengikuti penjajah yang tidak sesuai dengan prinsip agamanya, sehingga ia berhak menolak. Demikian pula saat dimintai tolong mewakili atau mendampingi orang yang terlibat kasus hukum, kemudian dapat menang secara hukum, dapat diartikan Kiai Sholeh sangat matang dalam berhujjah. Dalam cerita lain, pernah suatu kolam ikan gurami Kiai Sholeh terkena banjir, lalu minta ganti kepada Belanda, dan

${ }^{33}$ Wawancara dengan Miftachuddin, 11 Juli 2020 
entah bagaimana dikabulkan oleh pihak Belanda karena Mbah Kiai Sholeh ahli diplomasi ${ }^{34}$.

Cerita lain yang banyak dikisahkan terkait Kiai Sholeh adalah cerita saat Van Der Plas, pimpinan daerah saat itu yang berkunjung ke Kiai Sholeh. Saat itu Van Der Plas datang bersama rombongan sambil membawa anjing kesayangannya. Kemudian oleh Kiai Sholeh, anjing tersebut juga diminta didudukkan sama tinggi dengan tamu lainnya ${ }^{35}$. Sikap yang demikian buktinya tidak membuat para tamu dapat mengalahkan argumen yang dilontarkan Kiai Sholeh bahwa anjing tersebut merupakan kekasih dekat sang tamu, dan layaknya orang dekat ia layak mendapatkan penghormatan yang sama. Kisah ini mungkin juga dapat ditafsiri berbeda-beda sesuai dengan penangkapan pendengar. Yang jelas kisah tersebut termasuk kisah yang dilakukan oleh tokoh yang khariqul adat.

Kiai Sholeh dikenal sebagai pakar tauhid. Hal ini dapat diasumsikan bahwa sosoknya tidak hanya sebagai Kiai yang selalu berusaha dekat dengan tuhannya, tetapi juga mengajarkan kepada murid dan masyarakat untuk mengenal dekat Allah. Orang yang dekat dengan Allah seringkali dalam kisah-kisah keagamaan ditempeli keistimewaan/karomah oleh Allah. Sikap atau ucapannya seringkali bersifat simbolik yang bisa menimbulkan tanda tanya, tetapi menyimpan hikmah di belakangnya.

Di antara contoh keistimewaan Kiai Sholeh seperti yang diceritakan Al-Djaini berikut.

"Cerita dari Mbah Kiai Makruf Sukorejo: Dulu Mbah Kiai Sholeh naik dokar disuruh berhenti karena tidak boleh. Lalu dokar dituntun oleh Mbah Kiai Makruf. Musabab menuntun dokar ini, Mbah Kiai Makruf dan anak turunnya jadi orang alim. Di sini juga menunjukkan kontak batin antara guru dan murid."

"Rumah Mbah saya pernah dipakai mengaji oleh Mbah Kiai Sholeh, saat itu saya masih bayi. Mbah saya dulu kusir dan punya dokar. Beberapa kali Mbah saya mengantarkan Mbah Sholeh memberi pengajian ke Sumberglodok Nglegok Blitar.

${ }^{34}$ Wawancara dengan Al-Djaini, 22 Juli 2020

35 (Karomi, 2019; wawancara Miftachuddin, 9 Juli 2020) 
Saat akan mengantar Mbah Sholeh, kudanya Mbah saya itu jadi penurut, dipasangi tali dan disambungkan ke dokar juga menurut. Kemudian saat Mbah Sholeh naik, kuda tanpa dikomando dan dikendalikan Mbah saya, sudah bisa jalan sendiri, tahu arah tujuannya, dan sampai ditujuan berhenti sendiri." 36

Al-Djaini yang merupakan cucu dari murid dan pengikut setia Kiai Sholeh menarik-narik kesimpulan bahwa Kiai Sholeh memberikan berkah kepada murid dan keturunannya menjadi orang-orang yang saleh dan berilmu. Bahkan ia mendapat cerita dari para guru ngajinya yang berpendapat pula bahwa Kiai Sholeh termasuk dalam maqam waliyullah.

"Cerita lain dari Mbah Kiai Imam Mahdi. Pada waktu ia riyadloh di Batu Ampar, sempat tertidur. Dia bermimpi sedang menaiki kapal, dari Batu Ampar berhenti turun di makam Mbah Kiai Sholeh. Akhirnya dia menyimpulkan bahwa makam Mbah Kiai Sholeh ini 'sepadan' dengan makam di Batu Ampar."

"Cerita dari Ayah saya pula yang pernah mengaji di Mbah Kiai Sholeh, di Mbah Kiai Baweh, dan juga di Pucung, ia mengatakan: Dulu pernah diceritai oleh para sesepuh bahwa sebenarnya makam Batu Ampar dan makam Kuningan itu 'sepadan' hanya saja konstruk yang ada di umumnya masyarakat tentu menganggap bahwa makam Batu Ampar lebih tua. "37

Keanehan Kiai Sholeh juga sampai kepada saat menjelang wafatnya. Diceritakan bahwa dulu sebelum meninggal, Kiai Sholeh minta ditidurkan di pinggir sungai. Hingga saat ini tidak ada yang mengetahui alasan ataupun hikmahnya ${ }^{38}$.

\section{4) Masjid dan Pesantren}

Jika sang kakek dan ayah mendirikan masjid Nurul Huda dan pesantren di daerah Kuningan Kidul, Kiai Sholeh juga men-

\footnotetext{
${ }^{36}$ Wawancara dengan Al-Djaini, 22 Juli 2020

${ }^{37}$ Wawancara dengan Al-Djaini, 22 Juli 2020

38 Wawancara dengan Miftachuddin, 11 Juli 2020
} 
dirikan masjid An-Nur dan pesantren di Kuningan Lor. Lokasi kedua masjid ini sebenarnya sejajar berada di barat bantaran sungai di Kuningan. Jarak antara dua masjid ini kurang lebih terpaaut 2-3 kilometer. Masjid yang berada di dekat rumah induk sang Kiai dekat dengan sungai dan sumber air sebagai tempat bersuci yang paling mudah saat itu. Selain bahwa masjid juga dilengkapi kamar-kamar pondokan untuk para santri yang belajar pada kiai. Berbeda dengan peninggalan Syaikh Abu Hasan yang masih ada dan terjaga berupa pemondokan kayu hingga bancik (batu-batu pijakan) yang tertata sebanyak 99 buah dari halaman masjid hingga kolam sumber air, pemondokan hingga kolam dan batu pijakan bersuci sudah tidak lagi terlihat di Masjid An-Nur.

Masjid An-Nur dulunya merupakan musalla yang didirikan pada tahun 1910 M dengan dilengkapi pemondokan santri. Meskipun sudah mengalami renovasi dan berubah menjadi masjid, masih terdapat beberapa bagian yang masih dapat terlacak dan dibiarkan utuh pada bangunan masjid. Di antaranya tembok lingkar dalam, lubang pada pengimaman, angka tahun berdirinya masjid pada tembok depan, dan juga gambar bertulis pada tembok depan luar masjid. Detil deskripsi ini dapat dilihat dan diakses pada video yang diunggah di kanal youtube ${ }^{39}$.

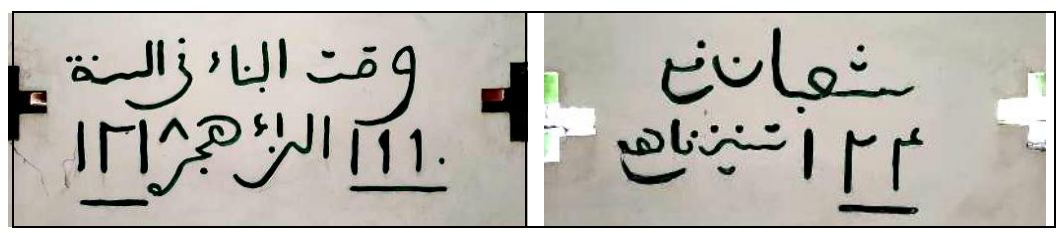

\section{Gambar 4.}

Inkripsi tahun pembangunan masjid An-Nur ${ }^{40}$

Gambar 4 menunjukkan waktu pembangunan masjid/ musalla An-Nur. Pada sisi kanan tertulis Syakban ping 23 Isnain Pahing (Senin Pahing 23 Syakban). Sedang pada sisi sisi kiri tertulis Waqtul Bina`Fis-Sanah 1910 az-Za`Hijrah 1218 (waktu pembangunan pada tahun $1910 \mathrm{M} / 1218$ Hijriah).

39 Cucubumi, Menelusur Peninggalan Mbah Kiai Sholeh Kuningan Blitar (Indonesia, 2020).

${ }^{40}$ Sumber: dokumentasi peneliti, Juli 2020 


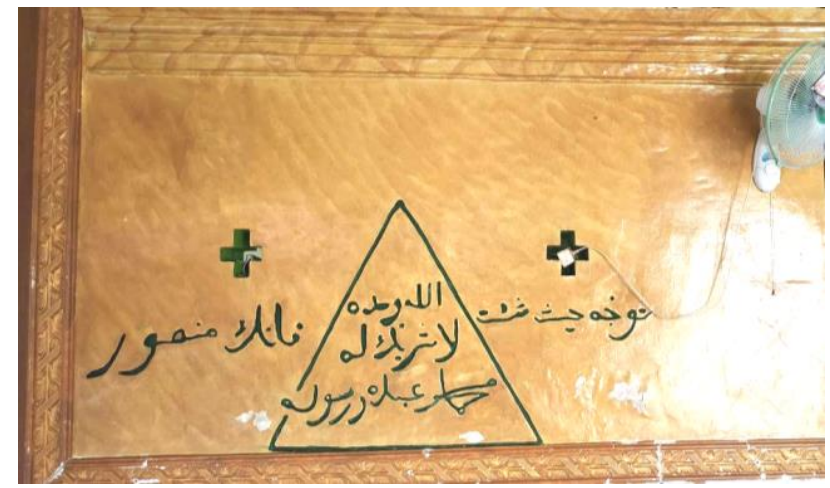

\section{Gambar 5.}

Inkripsi tauhid pada tembok masjid An-Nur ${ }^{41}$

Gambar 5 merupakan inkripsi segitiga tauhid yang juga sudah ada sejak dibangunnya masjid An-Nur ini. Secara lafal di luar segitiga tertulis Tawajjaha Haitsu Syi ta Fa Innaka Manshuurun (secara harfiah bermakna: Menghadaplah kearah manapun yang kau inginkan, sungguh engkau orang-orang yang ditolong). Sedangkan di bagian dalam segitiga tertulis redaksi Allahu Wahdahuu Laa Syariika Lahu Muchammadun 'Abduhuu wa Rasuuluhu (secara harfiah bermakna: Allah Maha Esa, tiada sekutu baginya, Muhammad adalah hamba dan utusan-Nya).

Adapun pemaknaan/maksud dari segitiga ini secara pasti belum dapat ditafsirkan oleh Miftachuddin selaku cucu tokoh. Menurutnya diperkirakan bahwa segitiga dalam referensi kitab Chusunul Hamidiyah bisa melambangkan hubungan Allah dengan makhluk-Nya, atau bisa juga melambangkan sifat-sifat Allah $^{42}$. Sedangkan maksud yang sesungguhya dari Kiai Sholeh belum didapatkan penulis.

Peninggalan fisik dari Kiai Sholeh yang terkait keagamaan sebenarnya terdapat bangunan asrama/pemondokan santri pada mulanya. Saat ini, bangunan pemondokan santri sudah dipugar dan menjadi bangunan baru, termasuk bentuk kamar mandi dan tempat wudlu, yang dulunya berupa bak bundar besar. Menurut

\footnotetext{
41 ibid

${ }^{42}$ Wawancara dengan Miftachuddin, 11 Juli 2020
} 
pengakuan Miftachuddin, santri tauhid tidak lagi bermukim di pemondokan masjid An-Nur, sehingga ruangan lebih digunakan sebagai tempat serbaguna. Hal ini terlebih karena sudah tidak adanya sosok pengasuh tauhid. Saat ini pembahasan tauhid tetap dilaksanakan di masjid An-Nur dalam bentuk musyawarah para santri tua yang tidak bermukim, tetapi laju tiap Sabtu malam membahas kitab Akaid Kiai Shaleh yang dipimpin Miftachuddin.

Meskipun santri tauhid seperti masa Kiai Sholeh sudah tidak ada di masjid An-Nur, tetapi pendidikan yang diwariskan Kiai Sholeh dikembangkan oleh ahli waris dalam bentuk yayasan yang membawahi Madrasah Diniyah Tarbiyatul Muballighin dan Taman Pendidikan Al-Quran Daarut Tauhid yang keduanya saat ini dipimpin oleh Miftachuddin.

\section{5) Kitab Akaid yang Terus Hidup}

Kiai Sholeh memiliki jariyah keilmuan berupa kitab yang saat ini dapat dijumpai sudah bentuk jilid fotokopi yang terdiri dari 4 juz dalam satu bendel dengan judul sampul Risalah Aqaid Litauhid. Menurut Miftachuddin, kitab asli tulisan tangan Kiai Sholeh kemungkinan masih ada dan dibawa/disimpan oleh cucu buyut (putra alm. KH. Misbahul Munir ibn KH. Bakir Sholeh ibn Kiai Sholeh) yang saat ini bermukim di Jakarta. Meskipun demikian, Miftachuddin juga belum bisa memastikan keberadaannya dan ia sendiri tidak yakin pernah melihat kitab aslinya.

Deskripsi kitab Kiai Sholeh ini dapat dilihat pada tabel berikut.

Tabel 1. Deskripsi naskah Risalah Aqaid Litauhid ${ }^{43}$

\begin{tabular}{lll}
\hline No & Unsur & Deskripsi \\
\hline 1 & Judul & Risalah Aqaid lit-Tauhid \\
2 & Pengarang & KH. Sholeh Ibn Abu Manshur Kuningan \\
3 & Penyalin & Muhammad Mustajab Ibn Abdul Mu'in \\
4 & Tahun Penulisan & - \\
5 & Tahun Penyalinan & $1407-1408 \mathrm{H}$ \\
6 & Pemilik & KH. Miftachuddin
\end{tabular}

43 Sumber: hasil olah data peneliti 
7 Jenis alas naskah Kertas Hvs

8 Kondisi fisik Baik

9 Panjang dan lebar $21,5 \times 33 \mathrm{~cm}$ naskah $(\mathrm{cm})$

10 Panjang dan lebar $18,5 \times 26 \mathrm{~cm}$ teks $(\mathrm{cm})$

11 Jumlah halaman Total $103 \mathrm{hlm}$.

Juz/teks 1: $16 \mathrm{hlm}$.

Juz/teks 2: $21 \mathrm{hlm}$.

Juz/teks 3: $21 \mathrm{hlm}$.

Juz/teks 4: 43 hlm.

12 Jumlah baris per Rata-rata 16 halaman

13 Penomoran Angka Arab halaman

14 Kata alihan

Tidak ada

15 Bahasa

Arab, Jawa

16 Aksara

17 Jenis khat

Arab Pegon

18 Warna tulisan

Naskhi

19 Kolofon

Hitam

20 Iluminasi

21 Ilustrasi

22 Baris awal dan baris akhir setiap teks dalam satu naskah

Ada

Juz/Teks 1.

Kalimat awal:

Bismillahirrahmaanirrachiim.

Alchamdulillahirabbi l 'aalamiin. wa s shalaatu wa s salaamu alaa asyrafi $l$ mursaliin wa alaa 'aalihi wa shahbihii 'ajma 'iin. Utawi mumkin iku roro... Kalimat akhir: ... nuli Allah iku ora sugih ing haale Allah ora sugih iku muhal. Wallaahu a'lam bi s shawaab. Alchamdulillaahi rabbi l'aalamiin. Juz/Teks 2.

Kalimat awal: Bismillahirrahmaanirrachiim. Alchamdulillahirabbi l 'aalamiin. was 
shalaatu wa s salaamu alaa asyrafi $l$ mursaliin wa alaa `aalihi wa shahbihii 'ajma 'iin. Qauluhu tusaamichu ay majaaz isti'aarah chaitsu syubbiha l wujuud bi s shifaati l chaqiiqati... Kalimat akhir: ... mesthi 'adam iku ta'alluq mufradat iku pada ingdalem ilmune chawaadits persifat tashawwur. Tammat wallaahu a'lam bi s shawaab. Alchamdulillaahi rabbil 'aalamiin. Juz/Teks 3.

Kalimat awal:

Bismillahirrahmaanirrachiim. Chamdan liman ja'ala dz Dzikraa naafi'atan lil mu 'miniina wa baysiiri ... wa ba'du fa yaquulu l 'abdu l faqiiru ilaa rahmati rabbihi l murtajaa...

Kalimat akhir: ... fii kutubi l 'aqaaidi wa t tashawwufi ka l ihyaa $i$ wa s sanuusii. Wallaahu a 'lam. Subchaana rabbika rabbi l izzati 'ammaa yasifuun wa salaamun ala l mursaliin walchamdulillaahi rabbi $l$ 'aalamiin. Juz/Teks 4.

Kalimat awal:

Bismillahirrahmaanirrachiim. Alchamdulillahirabbi l 'aalamiin. utawi lafadz al aalamiin iku lafadz ma'rifat ... Kalimat akhir: ... li walii muraqabatu $l$ af'aaliyah kelawan dzikr achadiyatu $l$ af'aal. H. Tammat haadzihi r risaalah wallaahu a'lam.

23 Ringkasan isi teks: Merupakan kitab akaid berbentuk deskriptif yang disusun dalam 4 jilid, sebagian berbahasa Arab dengan matan dan syarah di bawahnya, sebagian tanpa hanya matan tanpa harakat, sebagian lagi bercampur dengan bahasa Jawa. 
Kitab ini berdasar pengamatan para ahli waris dan juga beberapa informan merupakan beberapa nukilan yang di antaranya dikenali berasal dari kitab Hasiyah Ummul Barahin karya Imam Ad-Dasuqi. Meskipun demikian Mbah Sholeh tidak mengutip utuh, tetapi mengembangkan sendiri dengan pemahamannya. Para pembaca yang sudah akrab dengan kitab-kitab akaid akan dapat merasakan dan membedakan bagian-bagian yang merupakan kutipan dari kitab tertentu ${ }^{44}$.

Kitab ini ditulis dalam bahasa Arab dan Jawa Pegon, dengan aksara Arab. Pada juz 2 tertulis kolofon penyalinan kitab oleh Muhammad Mustajab ibn Abdul Muin, santri Pondok Pesantren Al-Mubarok Mojosari Nganjuk, tetapi identitas penulis ini belum dapat dikenali oleh ahli waris.

Kitab ini hingga saat ini masih hidup dan dikaji. Setidaknya yang masih berjalan dan diikuti oleh ahli waris adalah forum musyawarah di Masjid An-Nur Kuningan, serta pengajian umum akaid yang dibawakan oleh Kiai Muhammadun Sukorejo Blitar yang merupakan cucu salah satu murid Kiai Sholeh ${ }^{45}$. Selain dua forum ini, tentu di luar Kuningan atau bahkan di luar daerah Blitar menggelar kajian kitab Kiai Sholeh. Hal ini diperkuat dengan bukti penyalin kitab yang tertulis 'santri Mojosari Nganjuk', yang menandakan bahwa kitab ini juga dikenal oleh warga pesantren tua tersebut. Penelusuran jaringan dan pengaruh kitab karya Kiai Sholeh ini menarik untuk ditelusur lebih lanjut pada kajian berikutnya.

Pemangku tauhid setelah Kiai Sholeh di masjid An-Nur adalah Kiai Bakir Sholeh (putra Kiai Sholeh). Pengajian yang digelarnya dulu diikuti oleh banyak santri dan masyarakat tidak hanya dari kawasan Blitar. Ia juga termasuk kiai yang disegani. Miftachuddin menuturkan, dulu ia sering melihat banyak santri yang mengikuti pengajian Kiai Bakir ini selalu sudah turun dari sepeda dan menuntunnya sejak masuk ke pagar di depan jalan ${ }^{46}$.

${ }^{44}$ Wawancara dengan Arif M Shofwan, 8 Juli 2020; Miftahul Ulum, 12 Juli 2020; A Karomi, 15 Juli 2020

${ }^{45}$ Wawancara dengan Miftachuddin, 11 Juli 2020

46 ibid 
Pengajaran Aqaid saat ini berjalan pada generasi cucu Kiai Sholeh, yaitu diampu Bapak Miftachudin. Belum lama berselang, dua kiai yang merupakan cucu Kiai Sholeh yang lebih tua pengampu masjid An-Nur wafat. Mereka adalah KH. Misbahul Munir ibn KH. Bakir Sholeh dan KH. Baidlowi ibn H. Ali Rahmadani. Kiai Misbahul Munir merupakan alumni Lirboyo yang matang dalam pemahaman kitab, sedangkan Kiai Baidlowi alumni IAIN dan pesantren di Dawuhan Blitar yang unggul dalam segi kehumasan. Dulu pengajian dan musyawarah kitab Akaid Kiai Sholeh di masjid An-Nur diampu oleh Kiai Misbahul Munir, sedangkan madrasah dan masjid dipimpin Kiai Baidlowi. Setelah keduanya wafat kegiatan tersebut terlimpahkan kepada Miftachuddin, alumni bahasa arab IAIN Malang dan Magister UNISLA. Miftachudin yang merupakan pensiunan pengawas dan guru di Kementerian Agama Kab. Blitar menuturkan bahwa meskipun secara keilmuan belum secakap kakaknya (Kiai Misbahul Munir dan Kiai Baidlowi), ia tetaplah harus meneruskan tugas untuk ngurip-urip (menghidupkan) warisan keilmuan Kiai Sholeh melalui forum musyawarah kitab. Selain musyawarah pada Sabtu malam, ia juga terus aktif mengikuti kajian Akaid kepada Kiai Madun/Muhammadun Selorejo Blitar pada Minggu malam ${ }^{47}$.

Seperti yang penulis ikuti pada Sabtu malam, 11 Juli 2020. Redaksi yang dibahas dan dituliskan Pak Miftah hanya dua kata al ma'ani dan al ma'nawiyah beserta redaksi murad kecil berbahasa Arab tanpa syakal yang tertulis di bawahnya. Pembahasan sifat Allah ini dikutip dari bagian bawah halaman 2 juz pertama. Pembahasan dua hal tersebut berlangsung setidaknya dua jam. Pak Miftah yang menjadi penerus Kiai Sholeh saat ini mengaku belum berani memberikan kajian secara bandongan (satu arah) kepada masyarakat atau jamaah, dan lebih memilih metode musyawarah dengan sesama santri senior Kiai Madun. Niat utama Pak Miftah adalah menghidupkan kitab Kiai Sholeh dengan membaca, mendengar, dan memusyawarahkannya secara berkala meski telah khatam beberapa kali. Bagi Pak Miftah, siapapun yang mampu, boleh mengaji dan mengajarkannya,

47 ibid 
terlebih dari santri yang mengajinya secara bersanad hingga Kiai Sholeh $^{48}$.

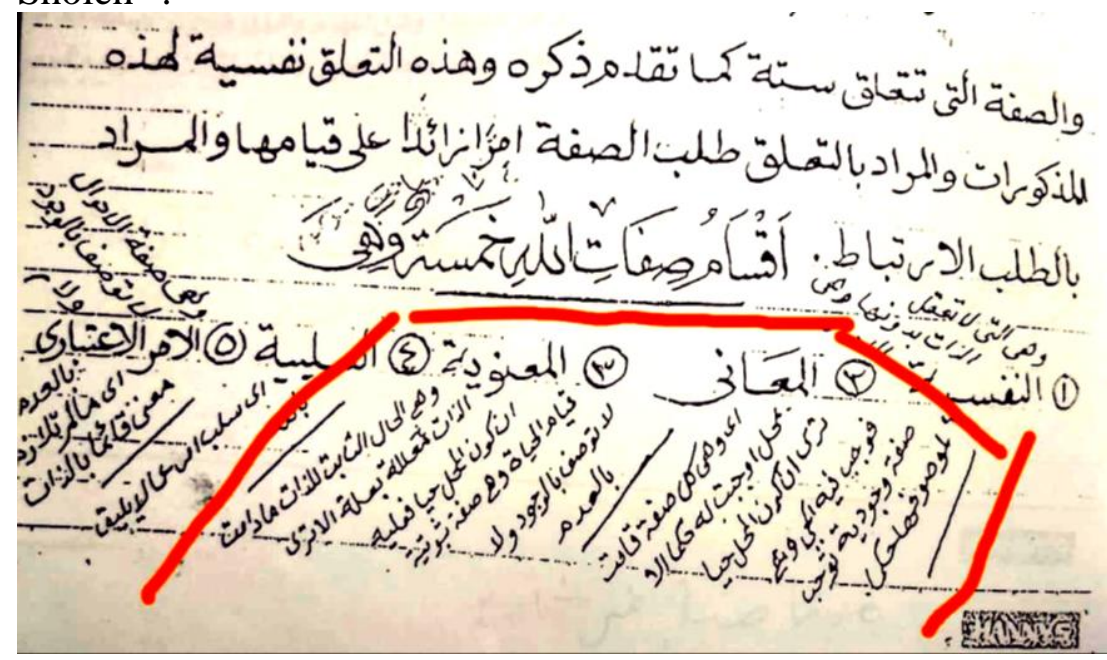

\section{Gambar 6.}

Maqalah pada musyawarah kitab 11 Juli $2020^{49}$

Kiai Madun/Muhammadun Selorejo merupakan cucu dari Mbah Sumo Sajam. Mbah Sumo Sajam dulunya adalah seorang bromocorah (preman) yang sangat pemberani. Setelah bertemu dengan Kiai Sholeh ternyata ia dapat ditaklukkan karena kalah kesaktian. Kiai Madun menuturkan bahwa dulu Kiai Sholeh ini mampu menembus tembok, hal yang tidak dapat dilampaui oleh Mbah Sumo Sajam. Pada akhirnya Mbah Sumo Sajam menjadi salah satu murid Kiai Sholeh yang pandai dalam bidang akaid hingga mengajar santri di musalla kecil yang ia dirikan. Tidak kalah unik, Kiai Madun sang cucu dari Mbah Sumo Sajam juga tidak dikenal sebagai alumni pesantren atau tepatnya tidak diketahui. Dulu saat berangkat mengaji ia berpamitan pergi mencari ikan. Meskipun demikian, menurut Miftachuddin Kiai Madun sangat cakap dalam membawakan kitab Akaid karya Mbah Sholeh, baik dalam pembacaan, pemahaman, dalil-dalil, hingga cara memahamkan kepada pendengar ${ }^{50}$.

\footnotetext{
48 ibid

${ }^{49}$ Sumber: Kitab Risalah Aqaid Litauhid Juz 1 hlm. 2

${ }^{50}$ Wawancara dengan Miftachuddin, 11 Juli 2020
} 
Selain forum kajian Kiai Madun, ada pula kajian kitab akaid ini yang diampu oleh Kiai Masduqi di Jeding Blitar. Akan tetapi, ia juga baru saja wafat dan saat ini belum ada yang meneruskan kajiannya. Kiai Masduqi adalah putra dari Kiai Salamun yang terkenal ahli akaid juga pada masanya. Kiai Salamun adalah murid sekaligus menantu Kiai Sholeh, yaitu suami dari anak bawaan isteri ketiga Kiai Sholeh ${ }^{51}$.

Forum kajian kitab akaid Kiai Sholeh diselenggarakan juga oleh genenasi kedua dari murid-murid yang lain yang tidak kesemuanya diketahui oleh Miftachudin. Misalnya saja kajian oleh Kiai Daiman, utara pasar Tlogo Kanigoro Blitar yang diikuti selama empat tahun oleh Shofwan. Selain kepada Kiai Daiman, Shofwan juga pernah mengikuti kajian di Kiai Imam Mahdi Sekardangan, Kiai Muhtar Fauzi Sekardangan, Kiai Madun Sukorejo, Kiai Misbahul Munir Kuningan, juga halaqah/diskusi di majelis kajian Kiai Madun. Sementara itu, pada generasi murid Mbah Sholeh pertama, kajian akaid salah satunya diselenggarakan oleh Mbah Kiai Sibaweh Baqhowi Tlogo, Mbah Kiai Ahmad Dasuqi Sekardangan, Mbah Kiai Sumo Sajam (ayah Kiai Madun Sukorejo), dan lainnya ${ }^{52}$.

\section{6) Kajian Kritis Kitab Aqaid Karya Kiai Sholeh}

Sub ini tidak dimaksudkan untuk melakukan kritik terhadap karya Kiai Sholeh, tetapi lebih sebagai usaha mengenalkan sekilas isi kepada pembaca terutama didasarkan dari pengalaman informan sekaligus penulis kedua dari artikel ini, Arif Muzayin Shafwan, yang pernah mengikuti kajian-kajian tauhid di wilayah Blitar. Kitab karya Mbah Kiai Sholeh yang banyak mengutip dan merujuk konsep tauhid Imam Asyari, Imam Maturidi, Imam Razi, Imam Dasuqi, Imam Syarqowi, Imam Zamakhsyari, Imam Ahfas, dan Imam Sanusi ini dapat dibedah atau dikaji sebagaimana berikut.

Pertama, menurut Kiai Sholeh dalam mempelajari hakikat ilmu tauhid perlu mengetahui lima hal terlebih dahulu; (1) dzat, yaitu sesuatu yang berdiri sendiri; (2) sifat, yaitu sesuatu yang

\footnotetext{
51 ibid

52 Wawancara dengan Arif M Shofwan, 9 Juli 2020
} 
berdiri kepada sesuatu yang lain; (3) berdirinya sifat pada tempat atau qiyamus shifat bi mahallin; (4) bersifatnya tempat dengan hukum sifat tersebut atau ittishaful mahalli bi hukmi tilkas shifat; dan (5) bergantungnya sifat dengan sesuatu yang mana sifat ilmu itu selalu bergantung padanya atau ta'alluqus shifat bi maa yata'allaqu bihil ilmu. Lima hal inilah yang yang dipakai untuk mengkaji dua puluh sifat-sifat wajib bagi Allah yang dikelompokkan ke dalam empat bagian berikut:

1. Sifat nafsiyah, ada satu yaitu: wujud.

2. Sifat salbiyah, ada lima yaitu: qidam, baqa', mukhalafatu lil hawaditsi, qiyamuhu bi nafsihi, dan wahdaniyat.

3. Sifat ma'ani, ada tujuh yaitu: qudrat, iradat, ilmu, hayat, sama', bashar, dan kalam.

4. Sifat ma'nawiyah, ada tujuh yaitu: qadiran, muridan, aliman, hayyan, sami'an, bashiran, dan mutakaliman.

Lima hal itu juga digunakan untuk mengkaji kebalikan dari kedua puluh sifat-sifat wajib bagi Allah di atas atau sifat mustahil bagi Allah. Dalam hal ini, kajian seperti di atas memiliki banyak kesamaan dengan kajian-kajian tauhid di Blitar yang berasal bukan dari tradisi pengkajian tauhid dari Mbah Kiai Sholeh, seperti kajian tauhid di kediaman Kiai Anwar Glondong, Kiai Anshar Muhammad Pondok Nur Mamba'ul Hisan Sembon, Kiai Muhammad Sananwetan, Kiai Mukayun Plosokerep, dan lainnya.

Kedua, Kiai Sholeh merumuskan bahwa dari kajian dua puluh sifat-sifat wajib bagi Allah (akaid) itu nantinya terkumpul dalam makna kalimat Lailahaillallah. Dalam hal ini, kitab tersebut menyebutkan ungkapan "Wa yaj'mau ma'na hadzihil aqa'idi qaulu Lailahaillallah", artinya dan terkumpullah makna akaid di atas dalam ucapan Lailahaillallah. Kajian dari Lailahaillallah adalah: "La" adalah La li nafyil jinsi yakni untuk menafikan segala jenis Tuhan. Di dalam " $L a$ " itu ada khabar berupa lafadz "maujud" yang dibuang (mahdzuf) yang mana biasa dimakni oleh santri pesantren "La Ilaha" (ora ono Pengiran kang wajib disembah iku maujud/tidak ada Sesembahan yang wajib disembah itu berwujud...), yakni kata " $i k u / i t u$ " dalam tradisi makna gandul ditandai dengan huruf " $k h a$ " yang berarti 
khabar dan kata "maujud" merupakan khabar yang dibuang (mahdzuf). Selanjutnya, kata "Illallah" itu merupakan isbat (menetapkan) hanya ada satu Tuhan yang wajib disembah yaitu Allah SWT. Dari hasil beberapa kajian kitab oleh generasi murid Mbah Kiai Sholeh yang diikuti Shofwan, seperti dalam majlis pengajian di Mbah Kiai Daiman Tlogo, Mbah Kiai Muhtar Fauzi dan Mbah Kiai Imam Mahdi Sekardangan, maka makna akaid yang sering diungkapkan sebagai berikut: 1) Sifat Wujud, "Laa Wujuda Illallah" artinya tidak ada wujud sejati kecuali hanya wujud Allah SWT. Sebab wujud yang lain itu wujudnya karena diwujudkan. 2) Sifat Qidam, "Laa Qidama Illallah" artinya tidak ada dahulu kecuali dahulu itu hanya dahulunya Allah. Sebab kalau ada dahulu-dahulu lain itu tetap bersifat baru (hawadist). 3) Sifat Baqa', "Laa Baqa'a Illallah", artinya tidak ada kekal kecuali kekalnya Allah. Sebab kalau ada kekal-kekal lain itu karena dikekalkan oleh Allah. Demikian seterusnya dengan pemahaman serupa terhadap 20 sifat wajib sisanya.

Hal-hal di atas sering digunakan sebagai perenungan oleh para pengkaji Kitab Risalah Aqaidut Tauhid karya Mbah Kiai Sholeh. Intinya, segala sesuatu selain Allah itu walau memiliki sifat-sifat seperti sifat wajib bagi Allah itu kapasitasnya hanya sebagai obyek (maf'ul bih) bukan sebagai subjek ( $f a$ 'il). Segala sesuatu yang selain Allah walau memiliki sifat-sifat seperti Allah tetap dihukumi terbatas (muqayyad). Sedangkan Allah selalu bersifat tak terbatas (mutlaq). Misalnya, seseorang kiai disebut 'alim" (yang mengetahui), tentu sifat 'alim'-nya ini beda dengan sifat 'alim'-nya Allah. Jika sifat 'alim'-nya Allah itu dihukumi tak terbatas (mutlaq), maka sifat 'alim'-nya seorang kiai dihukumi terbatas (muqayyad). Sebab 'alim'-nya seorang kiai itu karena di-alim-kan oleh Allah SWT. Sedangkan alim-nya Allah selalu berdiri sendiri (qiyamuhu bi nafsihi). Dalam kajian contoh sifat alim ini bisa dilanjutkan pada sifat-sifat Allah yang lainnya.

Untuk membedah makna Lailahaillalah ini, Mbah Kiai Sholeh banyak menggunakan logika ilmu nahwu. Seperti halnya ungkapan:

"utawi kumpule Laa lan isime miturut iku den arani ora makna sepuluh punjul siji kerana murakkab mazji kaya lafadz Ahada Atsara maknane sewelas ora makna sepuluh punjul siji, iku ora. 
Kapan-kapan Laa lan Ilaha iku mazji kaya lafadz Ahada Atsara, mangka ana apa Laa iku ngamal kaya ngamale Laitsa. Kapankapan ngamal kaya ngamale Laitsa mengkono, mangka dadi padha Lailahaillallah, padhane lafadz Laa Rajula Fid Dari (ora ono wong lanang siji ing ndalem omah), balik kang ana wong lanang akeh. Kapan-kapan mengono Laa kaya lafadz Laitsa, mangka dadi ono apa lafadz Laa ing ndalem kalimat Lailahaillah iku nuduhake amung suwiji kang nafi lan netepake pengiran akeh. Kapan-kapan mengkono, mangka ora afshah tauhide kelawan lafadz Lailahailllah..."53. (Adapun berkumpulnya 'La' dan isim-nya menurut hal itu disebut tidak bermakna sepuluh lebih satu karena susunan murakkab mazji seperti lafal ahada atsara yang maknanya sebelas, bukan bermakna sepuluh lebih satu, bukan, bukan seperti itu. Akan tetapi, saat 'La' dan 'Ilaha' itu mazji seperti lafal ahada atsara, maka 'La' itu beramal (istilah ilmu nahwu) seperti 'laitsa'. Ketika ber-amal seperti amal-nya 'laitsa' maka padanan untuk lafal 'laailaahaillaah' adalah lafal seperti 'laa rajula fid Dari'/tidak ada satu orang laki-laki di dalam rumah, tetapi bisa dimaknai 'bukan satu, tetapi banyak laki-laki di dalam rumah'. Jika lafal 'la' dimaknai seperti amal 'laitsa' yang demikian maka kalimat 'laailaahaillallah' bisa bermakna menafikan (hanya) satu tuhan, tetapi meyakini ada tuhan yang banyak. Jika pemaknaan lafal menjadi demikian, maka tauhid seseorang terhadap kalimat 'laailaaha illaallah'-nya tidak sah.)

Ketiga, Mbah Kiai Sholeh membahas tentang lafadz "Allah" sebagaimana berikut: "Utawi ismul muaddzom kang iya iku lafadz Allah ba'da Illa (lafadz Allah setelah Illa dalam kalimat Lailahaillah; pen) iku dudu hakikate pengiran, dudu. Anapun pengiran ingsun azza wa jalla iku pengiran kang dadi madlule lafadz: Allah, kang ora ana wilangane", artinya nama agung yaitu lafadz/nama Allah setelah Illa dalam Lailahaillah itu bukan hakikat Tuhan, bukan demikian. Adapun Tuhan saya itu adalah Tuhan yang ditunjukkan sifat-sifat-Nya oleh lafadz/nama: Allah, yang tanpa batas/mutlak ${ }^{54}$. Penjelasannya adalah bahwa "Allah" dalam kalimat Lailahailllah itu hanyalah nama dan

${ }^{53}$ Kitab Risalah Aqaidut Tauhid, hal. 10

${ }^{54}$ Kitab Risalah Aqaidut Tauhid, hal. 11 
bukan Tuhan sejati. Tuhan sejati adalah Tuhan yang sifat-sifatnya ditunjukkan pada nama/lafadz "Allah" tersebut. Disebutkan oleh Mbah Kiai Sholeh "Allah ismun lil musamma Allah"55, artinya Allah adalah nama untuk yang dinamai Allah.

Mbah Kiai Sholeh menyatakan: "Sebab kang nama Allah iku dudu Allah. Amung bae lafadz Allah iku nuduhake kang nama Allah. Sebab nama Allah iku kang den karepake iku kahanane Allah. Mangka kahanane Allah iku dzate Allah kang wujude ora kita weruhi (wujud dzat ghairu ma'lumatin lana), tapi wujude kita weruhi (wujuduhu ma'lumatun lana), sebab wujud iku dudu dzat (annal wujud ghairu dzat)" artinya sebab yang nama Allah itu bukan Allah. Hanya saja lafadz Allah itu menunjukkan yang bernama Allah. Sebab Allah yang dimaksud itu keadaan Allah. Padahal keadaan Allah itu dzat-nya yang wujudnya dzat tidak kita ketahui, tetapi wujudnya itu kita ketahui, sebab sesungguhnya wujud itu bukanlah dzat ${ }^{56}$.

Selanjutnya, Mbah Kiai Sholeh menyatakan: "anapun lafadz Allah iku aran keduwe dzat kang diarani (musamma)... alkhasil, utawi makrifat marang Allah iku mesthi paham dawuhe musonnif 'wa ma'nal lafdzu ma yu'na' (makna lafadz kang den maksud) utawa 'ma'nal ladzi ma yuqshodu minhu' (makna lafadz kang den maksud saka aran kasebut"57. Jadi intinya, jalan makrifat kepada Allah SWT itu harus memahami makna dari yang dimaksud nama Allah itu sendiri. Seperti halnya disebutkan di atas, Allah itu hanya nama. Sedangkan Allah yang sebenarnya adalah sifat-sifat yang ditunjukkan pada nama Allah tersebut.

Dalam hal di atas, apa yang dikaji Mbah Kiai Sholeh tentang lafadz "Allah" itu juga ditemukan dalam kajian-kajian tauhid di seputar Blitar, seperti halnya kajian Kitab Hakikatul Ma'arif karya Syaikh Muhammad Sirojul Arif di kediaman Kiai Anwar Glondong, Kiai Anshar Muhammad Pondok Pesantren Nur Mamba'ul Hisan Sembon, dan lainnya. Sebab jaman dahulu Syaikhona Kholil Bangkalan pernah menyatakan: "Kalau belajar ilmu hadist di Jombang. Kalau belajar ilmu fikih di Kediri.

${ }^{55}$ Kitab Risalah Aqaidut Tauhid, Juz 4 hal. 22

${ }^{56}$ Kitab Risalah Aqaidut Tauhid, Juz 2 hal. 8

${ }^{57}$ Kitab Risalah Aqaidut Tauhid, Juz 2 hal. 15 
Kalau belajar ilmu tauhid di Blitar" ${ }^{\text {58 }}$. Maka tak heran bila hingga kini banyak komunitas kecil kajian-kajian tauhid dan ilmu makrifat di seputar Blitar Raya. Hal ini juga menjadi gambaran bahwa pengkajian keilmuan terutama di bidang akaid pada masa itu bersifat inklusif, saling terkait/berpengaruh.

Keempat, Mbah Kiai Sholeh dalam kitabnya juga membahas makna "Muhammadur Rasulullah" (artinya Nabi Muhammad itu utusan Allah) dan menyebutkan bahwa Nabi Muhammad SAW itu pernah diutus oleh Allah SWT sebanyak empat kali ${ }^{59}$, yaitu:

1. Mursal bil fi'li fid dunya (diutus oleh Allah dengan perbuatan di dunia), yakni seperti halnya Nabi Muhammad SAW diperintah ketika jamannya wujud beliau sebagai manusia di dunia.

2. Mursal bil quwwah (diutus oleh Allah dengan kekuatan), yakni seperti halnya Nabi Muhammad SAW diutus memerintah pada orang-orang yang ada sebelum beliau ada di dunia, seperti memerintah sejak Nabi Adam hingga Nabi Muhammad SAW ada.

3. Mursal fiha (diutus di dalamnya), yakni seperti halnya Nabi Muhammad SAW diutus memerintah makhluk-makhluk sebelum beliau ada, seperti memerintah malaikatmalaikat.

4. Mursal bil fi'li fil akhirah (diutus melakukan perbuatan di akhirat), yakni seperti halnya Nabi Muhammad SAW diutus pada jaman hari kiamat nantinya.

Selain itu, Mbah Kiai Sholeh juga membahas nama/lafadz "Muhammad" dengan hitungan Abajadun. Dengan hitungan Abajadun ini, maka nama/lafadz "Muhammad" bisa dijumlah dengan jumlah sughra maupun kubra. Mbah Kiai Sholeh menyatakan bahwa apabila lafadz "Muhammad" dijumlah dengan jumlah sughra, maka jumlahnya ada 313 yang mengisyaratkan jumlah para nabi dan rasul yang pernah diutus oleh Allah SWT

${ }^{58}$ Informasi yang diperoleh Arif M Shofwan dari gurunya yaitu Alm. Kiai Zainuddin dan Alm. Kiai Imam Mahdi Sekardangan

${ }^{59}$ Kitab Risalah Aqaidut Tauhid, Juz 1 hal. 7 
ke dunia. Sementara jika lafadz "Muhammad" dijumlah dengan jumlah kubra, maka jumlahnya ada 124.000 yang mengisyaratkan jumlah para nabi yang pernah diturunkan oleh Allah ke dunia $^{60}$.

Kelima, Mbah Kiai Sholeh menyebutkan bahwa dalam belajar ilmu tauhid/makrifat ada dua rukun yang harus dipenuhi oleh pencari, yaitu: (1) Adillatul aqliyah, yakni dalil-dalil dari akal pikiran logis, dalam hal ini menggunakan piranti ilmu mantiq, dan semacamnya; dan (2) Syawahidun naqliyah, yakni perujukan-perujukan kepada dalil naqli berupa Al-Qur'an dan Al-Hadist. Dua hal itu menjadi rukun keimanan kepada Tuhan Yang Maha Kuasa. Dalam hal ini, segala yang berasal dari akal (aqli) harus diselaraskan dengan kedua dalil naqli (Al-Qur'an dan Al-Hadis) tersebut.

Kaitan dengan dalil akal (aqli), Mbah Kiai Sholeh dalam membahas ilmu tauhid pada kitab karangannya banyak menggunakan bangunan logika ilmu mantiq, seperti: logika yang digunakan ilmu mantiq adalah meliputi (1) qadhiyah awal atau premis satu; (2) qadhiyah tsani atau premis dua; dan (3) natijah atau kesimpulan. Pada halaman 25 Mbah Kiai Sholeh menggunakan displin ilmu mantiq berupa babul aks; (1) aks al-mustawi; (2) aks naqidh al mukhalif; (3) aks naqidh al-mufawwiq, dan lainnya. Hal inilah yang menjadi keunikan Mbah Kiai Sholeh dan generasi murid-muridnya dalam kajian-kajian tauhid/makrifat dibanding kajian-kajian ilmu tauhid/makrifat lain yang berada di seputar Blitar Raya. Sedangkan kaitan dengan dalil naqli, Mbah Kiai Sholeh banyak mengutip Al-Qur'an, seperti “Innallah ala kulli syai 'in qadiir", artinya Sesungguhnya Allah terhadap segala sesuatu itu Maha Kuasa, "Fa'lam annahu Lailahaillallah", artinya maka ketahuilah sesungguhnya tiada Tuhan selain Allah dan lain sebagainya.

Lain daripada hal di atas, Shofwan ketika mengaji ilmu tauhid/makrifat Mbah Kiai Sholeh di kediaman Mbah Kiai Daiman (murid generasi ke-2 dari Mbah Kiai Sholeh jalur Mbah Kiai Sibaweh Pondok Pesantren Al-Muslihun Tlogo), menyatakan: "Carane blajar ilmu tauhid/makrifat iku ono rena loro,

60 ibid 
yaiku: (1) cara belajar lmu tauhid/makrifat sing diibarakate ungkal kasar [alat pengasah pisau kasar; pen]; dan (2) cara belajar lmu tauhid/makrifat sing diibaratake ungkal alus [alat pengasah pisau halus; pen]." Menurut Mbah Kiai Daiman, cara belajar ilmu tauhid ala Mbah Kiai Sholeh itu ibarat cara belajar ilmu tauhid/makrifat dengan ungkal kasar. Ciri-ciri belajar ilmu tauhid/makrifat dengan ungkal kasar adalah menggunakan piranti-piranti (alat-alat) kasar seperti disiplin ilmu mantiq dan nahwu sharaf dalam membahasnya.

Sedangkan cara belajar ilmu tauhid/makrifat dengan ungkal alus menurut Mbah Kiai Daiman adalah cara belajar ilmu tauhid/makrifat yang telah menggunakan piranti-piranti (alatalat) halus dari unsur rasa (dzauq) atau sudah bercampur ilmu tasawuf dalam merealisasikan ilmu ketauhidan/kemakrifatan. Kategori kajian-kajian tauhid/makrifat dengan ungkal alus ini di seputar Blitar seperti halnya kajian Kitab Hakikatul Ma'arif karya Syaikh Muhammad Sirojul Arif di kediaman Kiai Anwar Glondong, Kiai Anshor Muhammad Pondok Pesantren Nur Mambaul Hisan Sembon dan lainnya. Belajar ilmu tauhid/makrifat melalui Kitab Al-Hikam karya Syaikh Ahmad bin Athaillah As-Sakandari juga dikategorikan menggunakan ungkal alus. Belajar ilmu tauhid/makrifat melalui konsep-konsep yang dibangun oleh Syaikh Abdul Madjid Ma'ruf (Wahidiyah) Kediri juga dikategorikan menggunakan ungkal alus.

Jika cara belajar ilmu tauhid/makrifat ala Mbah Kiai Sholeh (ungkal kasar) itu bisa dinamakan ilmu tauhid/makrifat secara konseptual, maka cara kedua yakni belajar ilmu tauhid/ makrifat dengan ungkal alus itu dinamakan ilmu tauhid/makrifat secara laku spiritual. Menurut Mbah Kiai Daiman bahwa kedua cara itu harus ditempuh para penuntut ilmu tauhid/makrifat, agar mendapatkan pemahaman konseptual dan laku spiritual yang sempurna dalam ketauhidan/kemakrifatan. Ibarat seseorang mengasah pisau, pertama kali harus menggunakan ungkal kasar. Selanjutnya, yang kedua kali/terakhir harus menggunakan ungkal alus. Dengan demikian, akan sempunalah asahan dari pisau tersebut. Dalam konteks belajar ilmu tauhid/makrifat, maka akan sempurnalah pemahaman ilmu tauhid/makrifat secara konseptual dan perealisasian ilmu tauhid/makrifat dengan cara laku spiritual. 
Keenam, Mbah Kiai Sholeh dalam kitab karyanya juga membahas dan mengajarkan cara zikir Lailahaillalah secara benar serta mengkritik orang yang mengucapkan kalimat tersebut tanpa memahami maknanya. Mbah Kiai Sholeh menyatakan: "...lan malih iku mukallaf lamun tho den takoni kaya apa mungguh makna kang dadi maknane zikir (Lailahaillah), embuh iyo mung ingsun weruh wong-wong padha ngucap Lailahaillah banjur ingsun melu-melu, lah iku mukallaf kang kaya mengkono iku babar pisan ora oleh bageyane sitheng galek iku sangka bagiane iman, balik iku mukallaf klebu bodo-bodone wongkang kerusakan, ora oleh manfaat babar pisan ing ndalem zikire iyo iku mukallaf', artinya... dan apabila ada orang mukallaf ditanya tentang makna zikir Lailahaillallah dia menjawab entah saya tidak tahu, saya cuma ikut-ikutan mengucapkan Lailahaillallah, maka mukallaf yang demikian itu sama sekali tidak mendapatkan bagian iman, tetapi mukallaf yang demikian itu termasuk bodohbodohnya manusia yang membuat kerusakan, dia tak mendapatkan manfaat dari apa yang dizikirkan ${ }^{61}$.

Tak jauh dari hal di atas, Mbah Kiai Sholeh menyatakan: "Dadi khasil lafadz Lailahallallah iku gunem cara Ngarobi gunem Allah, dadi wong guneman iku kudu weruh lan mangerteni marang kang den gunem, lan mukallaf ora dadi bahaya bodhone...", artinya telah menjadi berhasil lafadz Lailahailllah itu adalah perkataan cara Arab, perkataan Allah, jadi orang yang berkata itu harus mengetahui dan memahami kepada apa yang dikatakan, kalau demikian bagi mukallaf tidak membahayakan ${ }^{62}$. Dari sini jelas bahwa kalimat Lailahaillallah bagi Mbah Kiai Sholeh bukan hanya sekedar diucapkan dengan lisan, bahkan hanya dituliskan pada topi, bendera, dan semacamnya. Lebih dari itu, kalimat Lailahaillallah harus benar-benar diketahui dan dipahami maknanya.

Mbah Kiai Sholeh juga mengatakan: "Dadi maknane lafadz Lailahaillalah yen dadi zikir lafadze iku kudu weruh maknane kang iya mengkene, istbatul wahdaniyah lillah", artinya jadi makna lafadz Lailahaillallah itu apabila dipakai zikir

\footnotetext{
${ }^{61}$ Kitab Risalah Aqaidut Tauhid, Juz 3, hal. 6

${ }^{62}$ Risalah Aqaidut Tauhid, Juz 3, hal. 7
} 
harus mengetahui yang begini, yakni menetapkan keesaan kepada Allah (istbatul wahdaniyah lillah) ${ }^{63}$. Menurut Mbah Kiai Sholeh, Lailahalillallah itu dzikir nafi-istbat, yakni menafikan segala jenis Tuhan dan menetapkan satu Tuhan yaitu Allah. Oleh karena itu, orang yang berzikir dengan lafadz Lailahaillalah harus bisa menafikan dan mengistbatkan atau menetapkan yang demikian itu.

Dalam berbagai majelis kajian-kajian ilmu tauhid/makrifat di seputar Blitar, termasuk kajian-kajian dari murid-murid generasi Mbah Kiai Sholeh dinyatakan bahwa kalimat syahadat/tauhid itu harus benar-benar dipahami, tidak boleh hanya sekedar diucapkan. Apalagi kalau melihat budaya populer seperti saat ini, kadang kalimat syahadat/tauhid hanya menjadi trand budaya populer, seakan-akan hanya menulis kalimat syahadat/tauhid saja sudah dianggap bertauhid. Terkait kalimat syahadat/tauhid pada kata "Asyhadu" (Saya bersaksi), ini tentu juga dipertanyakan bagi penuntut ilmu tauhid/makrifat. "Apakah kita sudah benarbenar bersakasi?" ataukah kita hanya sekedar mengucapkan dengan lisan saja. Kita merasa "Asyhadu" (Saya bersaksi), ternyata kita masih "Aqulu" (Saya berkata). Tentu saja "kesaksian" kita tidak sah bagi kalangan ahli tauhid/makrifat.

Ketujuh, Mbah Kiai Sholeh menyebutkan bahwa orang yang ahli ilmu tauhid/makrifat itu dengan istilah "Al-Alim Bihi" atau "Al-Alim Billah" (artinya orang yang mengetahui Allah). Adapun orang yang disebut "Al-Alim Billah" adalah orang yang sudah memahami bab akal yang tujuh, yaitu: 1) Akal hayuli, 2) Akal firaq, 3) Akal fardu, 4) Akal kamil, 5) Kamilul akal, 6) Akal Sanubari, dan 7) Akal nafsu natiqah.

Dari ketujuh akal itu, maka mereka yang telah mencapai "akal nafsu natiqah" (yakni akal yang selalu berdialek) itu merupakan sifat bagi "Al-Alim Billah" artinya orang yang mengetahui Allah ${ }^{64}$. Mereka yang mencapai "akal nafsu natiqah" akan selalu melakukan tafakur (berdialek dengan dirinya sendiri): "Tafakkaru fi khalqillah wa laa tafakkaru fillah", artinya pikir-pikirkanlah tentang makhluk Allah, jangan memikirkan tentang dzat Allah.

\footnotetext{
${ }^{63}$ Kitab Risalah Aqaidut Tauhid, Juz 4, hal. 6

${ }^{64}$ Kitab Risalah Aqaidut Tauhid, Juz 3, hal. 5
} 
Orang yang telah mencapai "akal nafsu natiqah" akan selalu melakukan tadzakur "Undzuru maa dza fis samawati wal ardhi wa maa bainahuma", artinya nalar-nalarlah apa yang ada di langit dan bumi serta apa-apa yang ada di antara keduanya.

Kaitan dalam hal di atas, Mbah Kiai Sholeh lebih memilih istilah "Al-Alim Billah" daripada "Al-Arif Billah" bagi orang yang mengetahui Tuhan atau makrifat kepada-Nya. Ketika Shofwan menanyakan kepada gurunya Mbah Kiai Daiman (murid Mbah Kiai Sholeh generasi ke-2 jalur Mbah Kiai Sibaweh Pondok Pesantren Al-Muslihun Tlogo), ia menjawab bahwa Mbah Kiai Sholeh memilih istilah "Al-Alim Billah" karena Allah memiliki sifat "Al-Alim" (Yang Maha Mengetahui). Sedangkan Mbah Kiai Sholeh tidak memilih istilah "Al-Arif Billah" sebab Allah tidak memiliki sifat "Al-Arif".

Selain itu, Mbah Kiai Daiman juga menjelaskan dengan mengutip sebuah hadist yang berbunyi "Al-ulama waratsatul anbiya" artinya ulama itu pewaris para nabi (Al-Hadist). Ia lalu menjelaskan bahwa yang menjadi pewaris para nabi itu ulama, dan kata "Al-Alim" adalah mufrad dari jamak "Al-ulama" tersebut. Makanya, Mbah Kiai Sholeh lebih memilih istilah " $A l$ Alim" daripada "Al-Arif'. Demikianlah alasan yang diperoleh Shofwan saat mengaji Kitab Risalah Aqaidut Tauhid kepada Mbah Kiai Daiman.

Kedelapan, Mbah Kiai Sholeh menyatakan bahwa hukum akal (aqli) itu dibagi menjadi tiga, yaitu: (1) wajib; (2) mustahil; dan (3) jaiz. Menurutnya, barangsiapa yang memahami ketiga hal tersebut akan berhasil jalan untuk menuju makrifat. Dari memahami ketiga hal itu, menghasilkan zikir untuk mendekati perbuatan Allah (zikir muraqabatul af'al) dengan pemahaman "Laa Fa'ila Illallah", artinya tidak ada yang melakukan perbuatan kecuali hanya Allah ${ }^{65}$.

Demikianlah beberapa pembahasan dari Kitab Risalah Aqaidut Tauhid karya Mbah Kiai Sholeh. Biasanya ketika kajian kitabnya berlangsung penemuan-penemuan pemikiran itu semakin banyak. Terkadang ada yang mengaitkan temuan-temuan dalam kajian dengan konsep tauhid yang dibangun Syaikh Abdul

${ }^{65}$ Kitab Risalah Aqaidut Tauhid, Juz 4, hal. 42 
Majid Ma'ruf (Wahidiyah). Terkadang ada yang mengaitkan temuan-temuan dalam kajian dengan konsep tauhid yang ada dalam Kitab Hakikatul Ma'arif karya Syaikh Muhammad Sirojul Arif Kediri. Terkadang ada yang mengaitkan temuan-temuan dalam kajian dengan konsep-konsep Martabat Tujuh yang dibangun oleh Syaikh Muhyiddin Ibn Arabi, dan lainnya. Intinya, kajian-kajian tauhid itu biasanya tak ada yang given menjadi sebuah kesimpulan bersama, selalu ada pengembangan-pengembangan dalam berpikir ataupun tafakur.

Akhirnya, kajian ini terbatas dan terkendala oleh waktu dan kemampuan penulis untuk menelaah dan menelusur lebih lanjut. Setidaknya, kajian awal berupa penelusuran biografi Kiai Sholeh dan karyanya kitab akaid ini menunjukkan adanya jaringan keilmuan, kekerabatan, dan juga sanad yang memperkaya khazanah keilmuan Islam di nusantara. Di tigkat bawah, Kiai Sholeh telah menjadi saluran keilmuan yang menjadi perantara dari para ulama dan Kiai besar kepada para kiai dan santri yang ada di bawahnya/sekitarnya. Kiai perantara ini adalah jawaban dari pertanyaan sampainya ilmu dari para ulama kepada masyarakat, dan berperan sangat krusial.

\section{PENUTUP}

Kiai Sholeh Kuningan Blitar (1846-1948 M), penyusun kitab Risalah Aqaid Lit Tauhid merupakan salah satu kiai tauhid di Blitar yang banyak dirujuk. Secara nasab, Kiai Sholeh keturunan tokoh kiai besar yang juga berperan besar di lingkup daerah, selain juga jika dirunut masih mengarah kepada trah kerajaan Yogyakarta. Nasab keilmuan dan jejaring ulama semasa juga menambah khazanah dan wawasan Kiai Sholeh dalam bidang tauhid yang diungkapkan dalam karyanya. Salah satu contoh misalnya, berdasar klaim bahwa ia merupakan santri Syaikhona Kholil Bangkalan yang pakar Nahwu, Kiai Sholeh dapat menggunakan ciri khas keilmuan itu untuk membedah makna laa ilaaha illallaah.

Melalui dua metodologi yang digunakan, analisis tokoh dan wacana kritis yang digunakan, penulis dapat menyatakan bahwa sejauh ini dua metode tersebut cukup membantu dan tepat digunakan dalam kajian ini. Salah satu temuan dari sisi integritas 
tokoh, misalnya, pembaca dapat melihat gambaran contoh 'kiai desa' yang ada pada masa dulu. Bisa jadi, tokoh Mbah Kiai Sholeh dapat menjadi prototipe kiai desa itu, yang keras/tegas dalam hal tauhid atau ilmu agama, lebih mengesankan anti Belanda (penguasa), dan dikenal dekat terhadap masyarakat bawah. Sebutan 'mbah' yang dilekatkan kepada sang tokoh lebih sering didengar dan digunakan disbanding sebutan 'kiai', sementara dari sisi rasa, tentu sebutan pertama lebih dekat dan akrab. Bisa juga sebutan 'mbah' untuk menciptakan suasana yang lebih membumi. Sebagai tokoh agama di masyarakat, cerita tentang 'khariqul adat'/keanehan juga akrab didengar yang semakin menguatkan ketokohannya. Kemudian dari analisis kritis isi, pembaca juga dapat melihat bahwa peran Kiai Sholeh mewakili kiai desa sangat urgen dalam menjembatani keilmuan tauhid dan mewariskannya kepada para murid dan jamaah di masyarakat.

Pada akhirnya, kajian ini masih banyak menyisakan kekurangan yang perlu dilengkapi oleh para pembaca dan pengkaji selanjutnya, utamanya penelusuran naskah asli kitab serta identitas penyalin kitab yang beredar dan digunakan hingga saat ini. Demikian juga kajian terhadap isi kitab Kiai Sholeh ini juga masih terbuka lebar baik analisis kritis dari penulis lain, para santri, akademisi, juga analisis isi lainnya.

\section{DAFTAR PUSTAKA}

\section{Buku}

Azra, Azyumardi. 2004. Jaringan Ulama Timur Tengah Dan Kepulauan Nusantara Abad XVII \& XVIII: Akar Pembaruan Islam Indonesia. Jakarta: Kencana.

Bizawie, Zainul Milal. 2016. Masterpiece Islam Nusantara: Sanad Dan Jejaring Ulama-Santri (1830-1945). Tangerang Selatan: Pustaka Compass.

Darma, Yoce Aliah. 2009. Analisis Wacana Kritis. Bandung: Yrama Widya.

Dhofier, Zamakhsyari. 1982. Tradisi Pesantren: Studi Tentang Pandangan Hidup Kiai. Jakarta: LP3ES.

Harahap, Syahrin. 2006. Metodologi Studi Tokoh Pemikiran Islam. Jakarta: Istiqamah Mulya Press. 
- 2014. Metodologi Studi Tokoh Dan Penulisan Biografi. Jakarta: Prenadamedia Group.

Nasher, Moh. Jamal Abdul, Moh. Ajib, Muzamilfakih, Moh. Nor KH, Imam Maliki, and Anas Rosyidi. 2002. Buku Silsilah Keluarga Besar KH. Abu Manshur Kuningan. Blitar.

Ulum, Amirul. 2016. Muassis NU: Manaqib 26 Tokoh Pendiri Nahdlatul Ulama. Yogyakarta: Aswaja Pressindo.

\section{Artikel}

Marli, Zainal Anshari. 2016. "Pemikiran Pendidikan Islam KH. Mohammad Kholil Bangkalan." Turats 7, No. 1. http:// ejournal.iain-jember.ac.id/index.php/turats/article/view/ 153.

Masfiah, Umi. 2017a. "Pemikiran Kalam Kiai Muhammad Sami'un Purwokerto dalam Naskah Aqaid 50" .Jurnal SMART (Studi Masyarakat, Religi, Dan Tradisi) 3 (2): 207. https://doi.org/ https://doi.org/10.18784/smart.v3i2.

—. 2017b. "Pemikiran Pembaharuan KH. Abdul Wahab Chasbullah Terhadap Lahirnya Nahdlatul Ulama (NU)." International Journal Ihya' 'Ulum Al-Din 18 (2): 217. https://doi.org/10.21580/ihya.17.2.1737.

Muhakamurrohman, Ahmad. 1970. "Pesantren: Santri, Kiai, Dan Tradisi." IBDA : Jurnal Kajian Islam Dan Budaya 12 (2): 10918. https://doi.org/10.24090/ibda.v12i2.440.

Musfiroh, Musfiroh. 2019. "Peran Hadratus Syaikh Kh. Hasyim Asyari Dalam Pengembangan Hadis Di Indonesia." Holistic Al-Hadis 5 (1): 1. https://doi.org/10.32678/holistic.v5i1.3229.

Mustolehudin, Mustolehudin, and Siti Muawanah. 2018. "Pemikiran Pendidikan K. H. Ali Maksum Krapyak Yogyakarta." EDUKASI: Jurnal Penelitian Pendidikan Agama Dan Keagamaan 16 (1): 18-34. https://doi.org/10.32729/ edukasi. v16i1.441.

Nurochim, Nurochim, Eva Royandi, Agus Mauluddin, and Siti Ngaisah. 2020. "Multikulturalisme: Analisis Wacana Kritis Terhadap Teks Dalam Buku Ajar Pendidikan Agama Islam." Jurnal Lektur Keagamaan 18 (1): 197-222. https://doi.org/ 10.31291/ jlk.v18i1.775.

Rahmadi, Rahmadi. 2019. "Metode Studi Tokoh Dan Aplikasinya Dalam Penelitian Agama." Al-Banjari: Jurnal Ilmiah Ilmu-Ilmu Keislaman 18 (2): 274. https://doi.org/10.18592/al-banjari. 
v18i2.2215.

Satria, Budi Sujati. 2019. "Gambaran Ahmad Dahlan Dan Wahab Hasbullah Dalam Pendidikan Islam Terhadap Nasionalisme Indonesia." Al-Fikri 2 (Pendidikan): 28-36.

Setiyawan. 2013. "Sejarah Islam Nusantara Menurut Azyumardi Asra." Journal of Chemical Information and Modeling 53 (9): 1689-99.

Shoheh, Muhamad, and Muhammad Shofin Sugito. 2019. "Kitāb Seribu Masā'il Salinan Dari Banten: Sebuah Konstruksi Sejarah Proses Islamisasi Nusantara." Jurnal Lektur Keagamaan 17 (1): 1-30. https://doi.org/10.31291/jlk.v17i1.599.

Takdir, Mohammad. 2016. "Kontribusi Kiai Kholil Bangkalan Dalam Mengembangkan Tasawuf Nusantara." 'Anil Islam: Jurnal Kebudayaan Dan Ilmu Keislaman 9 (2): 268-99. http://jurnal. instika.ac.id/index.php/AnilIslam/article/view/18.

\section{Web}

Cucubumi. Menelusur Peninggalan Mbah Kiai Sholeh Kuningan Blitar. Indonesia, 2020.

Karomi, Ahmad. "Kisah Kiai Sholeh Kuningan Blitar Dan Anjing Milik Van Der Plas." halaqoh.net, 2019.

Ridwan, Roby. "Jejak Pasukan Diponego Penyebar Agama Islam Di Blitar." Youtube.com, 2018.

Rifa'i, Moh. Riwann. "Syaikhona Kholil Gurunya Para Kiai." nu.or.id, 2011.

2019. "Sejarah Singkat Wisata Religi Syaikh Abu Hasan Syaikh Abu Manshur Kuninangan Kec. Kanigoro Blitar," n.d.

\section{Informan}

Ahmad Karomi (Dosen UIN Sunan Ampel, alumni PP Ploso Kediri) tinggal di Blitar, masih keluarga Kuningan)

Arif Muzayin Shofwan (Dosen Universitas Nahdlatul Ulama Blitar)

Miftachuddin (Pensiunan Pengawas Kemenag, cucu tertua saat ini dari Mbah Sholeh)

Haikal Asfari (Juru kunci masjid dan makam Kuningan Dinas Kebudayaan Blitar, mantu buyut Mbah Sholeh)

Miftahul Ulum (Alumni Lirboyo, tinggal di Blitar)

Al-Djaini (Dosen STIT Al Muslihun Blitar) 